\title{
Physiological and molecular characterization of aluminum resistance in Medicago truncatula Divya Chandran ${ }^{1}$, Natasha Sharopova ${ }^{1}$, Kathryn A VandenBosch ${ }^{1,3}$, David F Garvin ${ }^{2,3,4}$ and Deborah A Samac*2,3,5
}

Address: ${ }^{1}$ Department of Plant Biology, University of Minnesota, 250 Biological Sciences Center, St. Paul, MN 55108, USA, ${ }^{2}$ USDA-ARS-Plant Science Research, St. Paul, MN 55108, USA, ${ }^{3}$ Center for Microbial and Plant Genomics, University of Minnesota, St. Paul, MN 55108, USA, ${ }^{4}$ Department of Agronomy and Plant Genetics, University of Minnesota, 411 Borlaug Hall St. Paul, MN 55108, USA and ${ }^{5}$ Department of Plant Pathology, University of Minnesota, 495 Borlaug Hall, St. Paul, MN 55108, USA

Email: Divya Chandran - divyachandran@berkeley.edu; Natasha Sharopova - sharo003@hotmail.com; Kathryn A VandenBosch - vande102@umn.edu; David F Garvin - garvi007@umn.edu; Deborah A Samac* - dasamac@umn.edu

* Corresponding author

Published: 19 August 2008

BMC Plant Biology 2008, 8:89 doi:10.1 I86/1471-2229-8-89
Received: 16 April 2008

Accepted: 19 August 2008

This article is available from: http://www.biomedcentral.com/I47/-2229/8/89

(C) 2008 Chandran et al; licensee BioMed Central Ltd.

This is an Open Access article distributed under the terms of the Creative Commons Attribution License (http://creativecommons.org/licenses/by/2.0), which permits unrestricted use, distribution, and reproduction in any medium, provided the original work is properly cited.

\begin{abstract}
Background: Aluminum (Al) toxicity is an important factor limiting crop production on acid soils. However, little is known about the mechanisms by which legumes respond to and resist Al stress. To explore the mechanisms of Al toxicity and resistance in legumes, we compared the impact of $\mathrm{Al}$ stress in Al-resistant and Al-sensitive lines of the model legume, Medicago truncatula Gaertn.

Results: A screen for Al resistance in 54 M. truncatula accessions identified eight Al-resistant and eight Al-sensitive lines. Comparisons of hydroponic root growth and root tip hematoxylin staining in an Al-resistant line, T32, and an Al-sensitive line, S70, provided evidence that an inducible Al exclusion mechanism occurs in T32. Transcriptional events associated with the Al resistance response were analyzed in T32 and S70 after 12 and 48 h Al treatment using oligonucleotide microarrays. Fewer genes were differentially regulated in response to Al in T32 compared to S70. Expression patterns of oxidative stress-related genes, stress-response genes and microscopic examination of Al-treated root tips suggested a lower degree of Al-induced oxidative damage to T32 root tips compared to S70. Furthermore, genes associated with cell death, senescence, and cell wall degradation were induced in both lines after $12 \mathrm{~h}$ of $\mathrm{Al}$ treatment but preferentially in S70 after $48 \mathrm{~h}$ of Al treatment. A multidrug and toxin efflux (MATE) transporter, previously shown to exude citrate in Arabidopsis, showed differential expression patterns in T32 and S70.
\end{abstract}

Conclusion: Our results identified novel genes induced by $\mathrm{Al}$ in Al-resistant and sensitive $M$. truncatula lines. In T32, transcription levels of genes related to oxidative stress were consistent with reactive oxygen species production, which would be sufficient to initiate cell death of Alaccumulating cells thereby contributing to Al exclusion and root growth recovery. In contrast, transcriptional levels of oxidative stress-related genes were consistent with excessive reactive oxygen species accumulation in $\mathbf{S 7 0}$ potentially resulting in necrosis and irreversible root growth inhibition. In addition, a citrate-exuding MATE transporter could function in Al exclusion and/or internal detoxification in T32 based on Al-induced transcript localization studies. Together, our findings indicate that multiple responses likely contribute to Al resistance in $M$. truncatula. 


\section{Background}

Aluminum (Al) toxicity is one of the important factors limiting crop productivity in acid soils $(\mathrm{pH}<5.0)[1]$, which occupy approximately $30 \%$ of the world's arable land [2]. Under acidic conditions, $\mathrm{Al}\left(\mathrm{H}_{2} \mathrm{O}\right)_{6}{ }^{3+}\left(\mathrm{Al}^{3+}\right)$ is released into the soil solution at levels that inhibit plant root growth and impair water and mineral uptake [3]. Despite decades of research on $\mathrm{Al}$ resistance, little is known about the mechanisms by which legumes respond to and tolerate Al stress. The model legume, Medicago truncatula Gaertn., which is a close relative of alfalfa, has a relatively small diploid genome, short generation time and prolific seed production [4] and therefore serves as an ideal model system to study Al toxicity and resistance mechanisms in legumes.

The root apex is considered to be the primary target of $\mathrm{Al}$ toxicity. Exposure of the root apex to $\mathrm{Al}$ results in a rapid inhibition of root growth [5]. Al disrupts root cell expansion and elongation, prior to inhibiting cell division [6] and interferes with a wide range of physical and cellular processes. Inhibition of root growth may occur as a result of Al-induced decrease in cell wall extensibility [7], callose formation [8], inhibition of $\mathrm{H}^{+}$-ATPase activity [9], disruption of calcium homeostasis [10], stabilization of cortical cell microtubules [11] and/or alteration in chromatin structure by DNA binding [12].

Many plant species exhibit significant genetic variability in their ability to resist and tolerate $\mathrm{Al}$ toxicity. M. truncatula exhibits a natural variation in tolerance to low $\mathrm{pH}$ [13] and Al toxicity [14]. Current models for $\mathrm{Al}$ resistance mechanisms include exclusion of $\mathrm{Al}$ from the root apex and internal detoxification of $\mathrm{Al}$ transported into the root symplasm [6]. Al-induced secretion of organic acid (OA)chelators is considered to be the primary mechanism of $\mathrm{Al}$ exclusion from the root apex. Also, chelation of Al by OAs within the root symplasm has been observed in some plant species [15]. A number of studies have indicated that OA chelation may not be the only mechanism responsible for $\mathrm{Al}$ resistance [16-19].

Over the last decade, researchers have debated whether the induced expression of genes or the activation of preformed proteins or both are necessary to combat $\mathrm{Al}$ toxicity. The biochemical machinery for root $\mathrm{Al}$ exclusion via organic acid release appears to be in place before exposure to $\mathrm{Al}$ in some species $[20,21]$. In other species a delay in secretion is observed, indicating that gene induction may be required [22-24]. Several studies have identified genes that are up-regulated under $\mathrm{Al}$ stress conditions. However, most of these genes were considered to be general stress response genes since they were induced in response to other stresses (other metal toxicities, low $\mathrm{Ca}$, wounding and oxidative stress) and to similar levels in both Al-resistant and $\mathrm{Al}$-sensitive genotypes [25-30].
In this report, we identified Al-resistant and Al-sensitive M. truncatula lines and quantified differences in $\mathrm{Al}$ effects on root physiology and gene expression between these lines. Based on our findings we propose that multiple responses including $\mathrm{Al}$ exclusion by $\mathrm{Al}$-induced cell death of Al-accumulating cells and organic acid efflux and internal detoxification by $\mathrm{OA}$ chelation may contribute towards higher $\mathrm{Al}$ resistance in $\mathrm{M}$. truncatula.

\section{Results and Discussion \\ Identification of Al-resistant and Al-sensitive M. truncatula}

Plants from $54 \mathrm{M}$. truncatula accessions were screened using a hydroponic assay with $2.5 \mu \mathrm{M} \mathrm{Al}$ concentration. At this $\mathrm{Al}$ concentration, the relative root growth (RRG) of the reference $M$. truncatula genotype A17 was 33\%. In a previously published study [31], $0.1 \mathrm{~N} \mathrm{KOH}$ was used to adjust the $\mathrm{pH}$ of the $\mathrm{Al}$ solutions to 4.5. The addition of base can result in the hydrolysis of $\mathrm{Al}\left(\mathrm{H}_{2} \mathrm{O}\right)_{6}{ }_{6+}{ }^{3+}\left(\mathrm{Al}^{3+}\right)$ into monomeric species such as $\mathrm{Al}\left(\mathrm{H}_{2} \mathrm{O}\right)_{5} \mathrm{OH}^{2+}$ [32]. This could have potentially lowered the concentration of the toxic form of $\mathrm{Al}\left(\mathrm{Al}^{3+}\right)$ in the solution. In the current study, we avoided the use of base. Therefore, similar levels of root growth inhibition as obtained previously were achieved by using 10 -fold lower $\mathrm{Al}$ concentrations in the current study.

The RRG values of the different lines were normalized to that of A17 to rank them according to their level of resistance. Eight lines with normalized values greater than 2.0 were considered Al-resistant and eight lines with values below 0.5 as Al-sensitive (Table 1). No correlation was observed between seed size and root growth (data not shown). An Al-resistant line generated from a single seed of the accession PI 384662 from Morocco (designated T32), and an Al-sensitive line similarly derived from the Italian accession PI577613 (designated S70), were selected to study physiological and molecular aspects of $\mathrm{Al}$ resistance. T32 showed the highest RRG in Al solution and was the obvious choice for the resistant line. Although S70 was not the most $\mathrm{Al}$-sensitive line in the screen, it was selected because plant to plant variation in root growth in nutrient solution was minimal compared to other Al-sensitive lines and root growth rates of S70 were most similar to that of T32 in control solutions (72 h root growth of T32 in control solutions was $13 \mathrm{~mm}$ while that of S70 was $15.8 \mathrm{~mm}$ ).

\section{Aluminum dose-response root growth}

Relative root growth of A17, T32, and S70 decreased in an $\mathrm{Al}$ dose-dependent manner over $48 \mathrm{~h}$ of $\mathrm{Al}$ exposure (Figure 1). However, differences in $\mathrm{Al}$ resistance between $\mathrm{T} 32$ and S70 were observed at all $\mathrm{Al}$ concentrations evaluated. At lower solution $\mathrm{Al}$ concentrations (1.25 and $2.5 \mu \mathrm{M})$, T32 exhibited the highest RRG values $(120 \%$ and $90 \%$, respectively), followed by A17 (70\% and 35\%, respec- 
Table I: Mean relative root growth $(n=6)$ of $M$. truncatula lines after $2 \mathrm{~d}$ of growth in $2.5 \mu \mathrm{M}$ Al solution.

\begin{tabular}{|c|c|c|c|c|c|c|}
\hline Line Designation & Accession Number & Country of Origin & $\begin{array}{l}\text { Relative root growth } \\
\text { (RRG) }\end{array}$ & $( \pm) S E$ & $P$-value $(*<0.05 * *<0.01)$ & $\begin{array}{c}\text { RRG } \\
\text { (normalized to } \mathrm{Al} \text { ) }\end{array}$ \\
\hline & & & USDA Collection & & & \\
\hline A32 (T32) & PI 384662 & Morocco & 0.93 & 0.05 & $0.001 * *$ & 2.92 \\
\hline A43 & PI 577628 & Spain & 0.91 & 0.09 & $0.000 * *$ & 2.85 \\
\hline A4I & PI 319045 & Spain & 0.88 & 0.05 & $0.000 * *$ & 2.75 \\
\hline A84 & W6 6050 & Tunisia & 0.88 & 0.17 & $0.000 * *$ & 2.74 \\
\hline AlO & PI 19736I & Australia & 0.81 & 0.11 & $0.000 * *$ & 2.52 \\
\hline A62 & PI 464815 & Turkey & 0.80 & 0.28 & $0.001 * *$ & 2.50 \\
\hline A47 & W6 6099 & Portugal & 0.71 & 0.09 & $0.000 * *$ & 2.20 \\
\hline A36 & PI 516937 & Morocco & 0.67 & 0.13 & $0.000 * *$ & 2.08 \\
\hline A85 & W6 6110 & Italy & 0.63 & 0.11 & $0.000 * *$ & 1.97 \\
\hline A55 & W6 6000 & France & 0.60 & 0.07 & $0.000 * *$ & 1.88 \\
\hline A34 & PI 516927 & Morocco & 0.60 & 0.08 & $0.000 * *$ & 1.87 \\
\hline A77 & W6 6012 & Italy & 0.59 & 0.09 & $0.001 *$ & 1.85 \\
\hline A91 & PI 577617 & Greece & 0.59 & 0.03 & $0.000 * *$ & 1.84 \\
\hline A65 & PI 577434 & Tunisia & 0.58 & 0.08 & $0.001 * *$ & 1.81 \\
\hline Al00 & W6 5983 & Cyprus & 0.56 & 0.10 & $0.003 * *$ & 1.75 \\
\hline A50 & PI 577608 & France & 0.55 & 0.15 & $0.018 *$ & 1.70 \\
\hline All & PI 243884 & Australia & 0.54 & 0.12 & $0.012 *$ & 1.69 \\
\hline A28 & PI 384636 & Morocco & 0.52 & 0.06 & $0.005 * *$ & 1.63 \\
\hline $\mathrm{A} 12$ & PI 442892 & Australia & 0.50 & 0.09 & $0.020 *$ & 1.56 \\
\hline A88 & PI 577599 & Greece & 0.49 & 0.13 & 0.052 & 1.54 \\
\hline $\mathrm{A} 3$ & PI 190084 & Australia & 0.49 & 0.09 & $0.028 *$ & 1.53 \\
\hline A87 & PI 566887 & Greece & 0.48 & 0.21 & 0.183 & 1.49 \\
\hline A89 & PI 57760I & Greece & 0.47 & 0.12 & 0.087 & 1.46 \\
\hline AlOI & W6 5984 & Cyprus & 0.44 & 0.06 & 0.083 & 1.38 \\
\hline $\mathrm{A} 2 \mathrm{I}$ & PI 57764I & Australia & 0.42 & 0.10 & 0.210 & 1.31 \\
\hline Al5 & PI 469099 & Australia & 0.38 & 0.07 & 0.438 & 1.19 \\
\hline A40 & PI 244285 & Spain & 0.38 & 0.07 & 0.427 & 1.18 \\
\hline A66 & PI 577619 & Tunisia & 0.35 & 0.15 & 0.787 & 1.10 \\
\hline \multirow[t]{2}{*}{$\mathrm{A} 5$} & PI 190089 & Australia & 0.34 & 0.05 & 0.852 & 1.06 \\
\hline & Al7 & Australia & 0.33 & 0.03 & NA & 1.00 \\
\hline A92 & PI 577618 & Greece & 0.31 & 0.11 & 0.818 & 0.97 \\
\hline A93 & PI 577604 & Cyprus & 0.30 & 0.07 & 0.690 & 0.94 \\
\hline Al 8 & PI 517257 & Australia & 0.28 & 0.16 & 0.633 & 0.88 \\
\hline A82 & W6 6047 & Tunisia & 0.28 & 0.03 & 0.418 & 0.87 \\
\hline Al7 & PI 469102 & Australia & 0.27 & 0.05 & 0.374 & 0.85 \\
\hline A42 & PI 31905I & Spain & 0.23 & 0.08 & $0.000 * *$ & 0.72 \\
\hline A76 & W6 5964 & Italy & 0.23 & 0.04 & 0.112 & 0.71 \\
\hline Al9 & PI 566888 & Australia & 0.19 & 0.07 & $0.044 *$ & 0.60 \\
\hline A90 & PI 577602 & Greece & 0.17 & 0.08 & $0.026 *$ & 0.53 \\
\hline A70 (S70) & PI 577613 & Italy & 0.15 & 0.02 & $0.002 * *$ & 0.48 \\
\hline A60 & PI 5776|4 & Malta & 0.15 & 0.10 & $0.028 *$ & 0.48 \\
\hline A7 & PI I9009| & Australia & 0.15 & 0.09 & $0.018 *$ & 0.48 \\
\hline $\mathrm{A} 3 \mathrm{I}$ & PI 384660 & Morocco & 0.15 & 0.04 & $0.012 *$ & 0.47 \\
\hline A4 & PI 190087 & Australia & 0.14 & 0.04 & $0.004 * *$ & 0.44 \\
\hline A56 & PI 493295 & Portugal & 0.13 & 0.07 & $0.005 * *$ & 0.40 \\
\hline A48 & PI 535739 & Libya & 0.12 & 0.05 & $0.002 * *$ & 0.39 \\
\hline \multirow[t]{10}{*}{ A79 } & W6 6025 & Italy & 0.08 & 0.06 & $0.001 * *$ & 0.26 \\
\hline & & & French Collection & & & \\
\hline & DZA45.5 & Algeria & 0.61 & 0.08 & $0.000 * *$ & 1.91 \\
\hline & TN8.3 & Tunisia & 0.41 & 0.04 & 0.132 & 1.28 \\
\hline & TNI.II & Tunisia & 0.35 & 0.03 & 0.656 & 1.10 \\
\hline & F83005.9 & France & 0.33 & 0.14 & $0.94 I$ & 1.04 \\
\hline & F8005.5 & France & 0.30 & 0.03 & 0.586 & 0.93 \\
\hline & A20 & Australia & 0.25 & 0.05 & 0.207 & 0.80 \\
\hline & DZA3I5.16 & Algeria & 0.24 & 0.03 & 0.099 & 0.74 \\
\hline & TN6.18 & Tunisia & 0.19 & 0.11 & 0.124 & 0.59 \\
\hline
\end{tabular}

RRG, Ratio of root growth in $2.5 \mu \mathrm{M}$ Al solution to root growth in $0 \mu \mathrm{M}$ Al solution; SE, standard error of the mean; $P$-value, significance comparing mean relative root growth for each line with that of AI7. Student's t-test (assuming equal variance) using a two-tailed distribution was employed for the statistical test. 
tively), and S70 (65\% and 15\%, respectively). The maximum difference in RRG between T32 and S70 was observed at $2.5 \mu \mathrm{M}$ solution $\mathrm{Al}$ concentration.

Within the first $24 \mathrm{~h}$ of Al treatment, root growth inhibition in T32 occurred at all Al concentrations tested except at $1.25 \mu \mathrm{M} \mathrm{Al}$ (Figure 2a). In $1.25 \mu \mathrm{M}$ solution Al concentration the root growth of T32 seedlings was approximately $20 \%$ higher than the control seedlings after $24 \mathrm{~h}$. This phenomenon has been observed in wheat, and it was suggested that enhanced root growth might be the result of alleviation of $\mathrm{H}^{+}$stress under acidic conditions by $\mathrm{Al}$ [33]. Alternatively, addition of $\mathrm{Al}$ to the nutrient solution may influence the bioavailability of other ions in a manner that stimulates growth [34]. Interestingly, it has been shown that the low concentration Al-induced increase in root growth of Quercus serrata was not caused by the amelioration of $\mathrm{H}^{+}$toxicity by $\mathrm{Al}$ [35]. In contrast, root growth inhibition occurred at all Al concentrations in S70 at $24 \mathrm{~h}$ (Figure 2b). By $72 \mathrm{~h}$, recovery of root growth to control rates was observed in T32 at $2.5 \mu \mathrm{M}$ Al. Depletion of Al from the nutrient solution is not a likely explanation for this result given the large solution volume and small root mass involved. In S70, no recovery was observed and root growth inhibition appeared to be constant throughout the time course of the experiment. The stimulation of root growth at $1.25 \mu \mathrm{M} \mathrm{Al}$ and recovery of root growth at 2.5 $\mu \mathrm{M} \mathrm{Al}$ suggests that the $\mathrm{Al}$ resistance of $\mathrm{T} 32$ is inducible. In an Al-resistant maize cultivar, there was a lag time of more than $4 \mathrm{~h}$ before the root tips were efficiently pro-

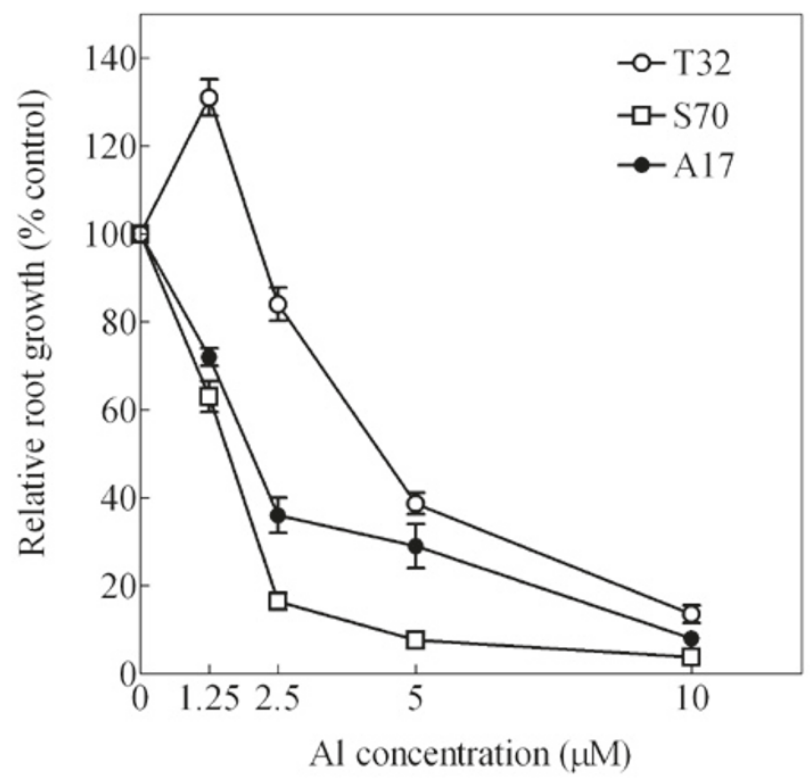

Figure I

Effect of Al-dose on root growth in M. truncatula. RRG \pm SE of T32, AI 7 and S70 seedlings grown at I.25, 2.5, 5 and $10 \mu \mathrm{M} \mathrm{Al}$ for $48 \mathrm{~h}$. tected against Al toxicity [36]. Similarly, in $2.5 \mu \mathrm{M} \mathrm{Al}$ solutions, a lag period between $\mathrm{Al}$ stress perception and functional expression of induced $\mathrm{Al}$ resistance would explain the observed root growth inhibition and recovery pattern in $\mathrm{T} 32$.

\section{Al accumulation in T32 and S70 root tips}

The degree of hematoxylin staining in root tips provides a semi-quantitative measure of $\mathrm{Al}$ content, and is inversely
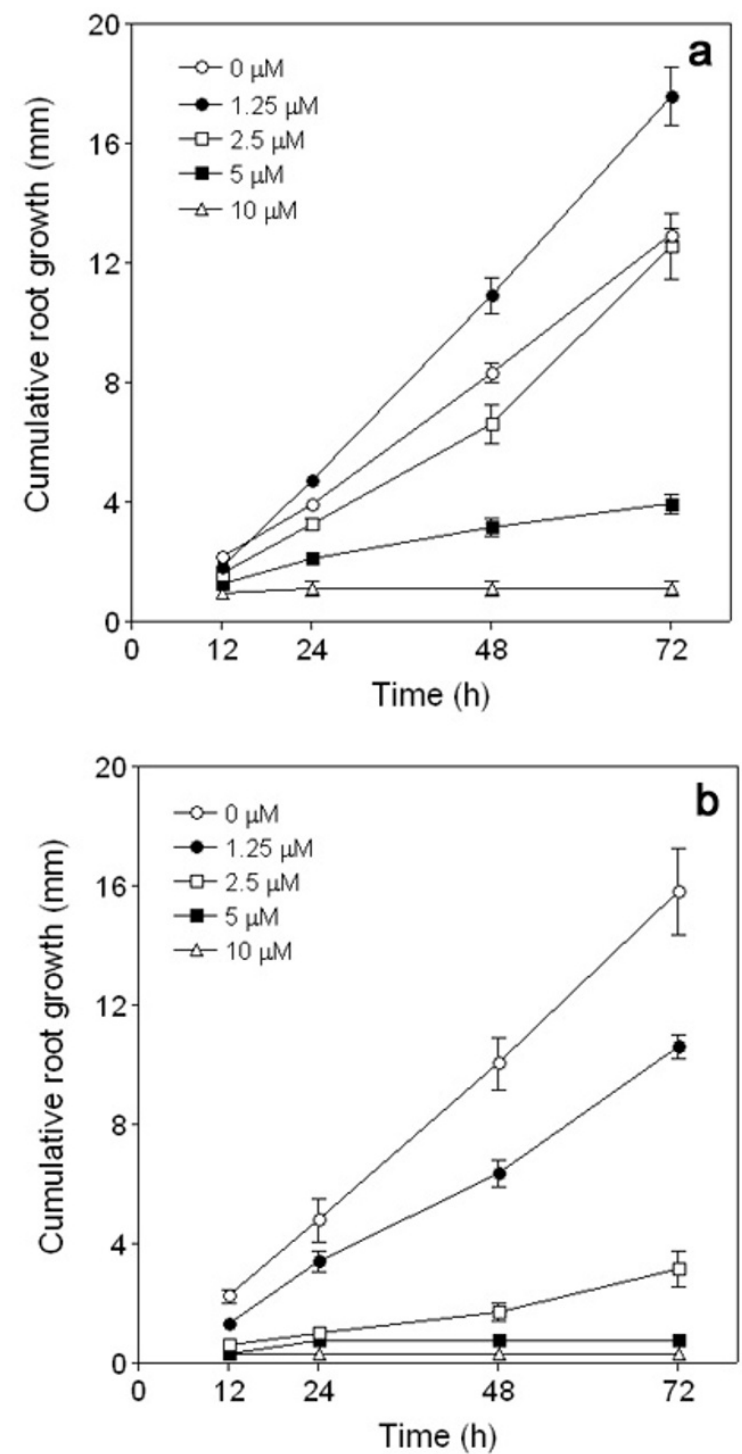

\section{Figure 2}

Effect of Al-dose and time on root growth of M. truncatula. Cumulative root growth of seedlings exposed to 0 , I.25, 2.5, 5 and $10 \mu \mathrm{M}$ Al for 12, 24, 48 and $72 \mathrm{~h}$. Data represent the mean root growth values \pm SE of eight seedlings from three independent experiments. (a) T32 seedlings. (b) S70 seedlings. 
proportional to both the ability of a genotype to exclude $\mathrm{Al}$ from the root apex, and its $\mathrm{Al}$ resistance [37]. The greatest differentiation between T32 and S70 was observed at $2.5 \mu \mathrm{M} \mathrm{Al}$, at which root tips of T32 exhibited minimal staining and root tips of S70 were more intensely stained (Figure 3a). Similar differences were observed at $5 \mu \mathrm{M} \mathrm{Al}$. However, at $10 \mu \mathrm{M} \mathrm{Al}$, root tips of both lines were intensely stained, indicating an inability to effectively exclude $\mathrm{Al}$ at such high concentrations.

Roots of T32 and S70 were stained with hematoxylin following different lengths of exposure to $2.5 \mu \mathrm{M} \mathrm{Al}$ to determine whether the recovery in root growth observed in T32 was a consequence of a decrease in $\mathrm{Al}$ accumulation in the root tips. Within $12 \mathrm{~h}$ of Al treatment, root tips of both lines were lightly stained (Figure $3 \mathrm{~b}$ ). By $72 \mathrm{~h}$, no staining was observed in T32. In contrast, root tips of S70 were intensely stained. The increased $\mathrm{Al}$ resistance of T32 may depend on an induced ability to exclude $\mathrm{Al}$, since no visible hematoxylin staining was observed in T32 root tips at $72 \mathrm{~h}$. If Al exclusion is inducible in $\mathrm{T} 32$, the $\mathrm{Al}$ that was initially taken up by the roots would still be present, and would likely be visible by hematoxylin staining. Figure $3 \mathrm{~b}$ shows visible hematoxylin staining approximately $3 \mathrm{~mm}$ from the root tip at $48 \mathrm{~h}$ of Al treated roots (black arrow), demonstrating that $\mathrm{Al}$ had accumulated in root cells prior to root growth recovery. In contrast, S70 root tips showed increased $\mathrm{Al}$ accumulation coupled with severe cell damage that extended 1 to $2 \mathrm{~mm}$ behind the root tip (Figure $3 \mathrm{~b})$. This pattern of injury is similar to previous observations in Al-sensitive maize root apices [38]. The hematoxylin staining result is concordant with the root growth data, indicating that greater $\mathrm{Al}$ accumulation is correlated with greater root growth inhibition in M. truncatula.

\section{Differential expression of genes in response to Al}

The molecular responses underlying differences in $\mathrm{Al}$ resistance were investigated using the M. truncatula AROS (version 1.0) arrays (Operon Biotechnologies Inc., Huntsville, AL) consisting of probes for approximately 16,000 $M$. truncatula expressed genes. Al-induced gene expression was compared in T32 and S70 after 12 and $48 \mathrm{~h}$ of $+/-2.5$ $\mu \mathrm{M} \mathrm{Al}$ treatment. We selected $12 \mathrm{~h}$ since root growth inhibition was observed at that time point in T32. We selected the $48 \mathrm{~h}$ time point since root growth rates recovered to that of the controls by $72 \mathrm{~h}$ in T32. These time points were chosen to identify transcriptional differences associated with Al-toxicity and resistance responses between the two lines. To detect significant genes with Al-regulated expression and to eliminate those that have inconsistent expression data among replicated experiments, we employed a statistical method adapted specifically for microarrays, which allows estimation of the false discovery rate (FDR) for multiple testing [39]. A delta criterion that allowed a FDR $<0.5 \%$ was applied. Genes that satisfied the statisti-
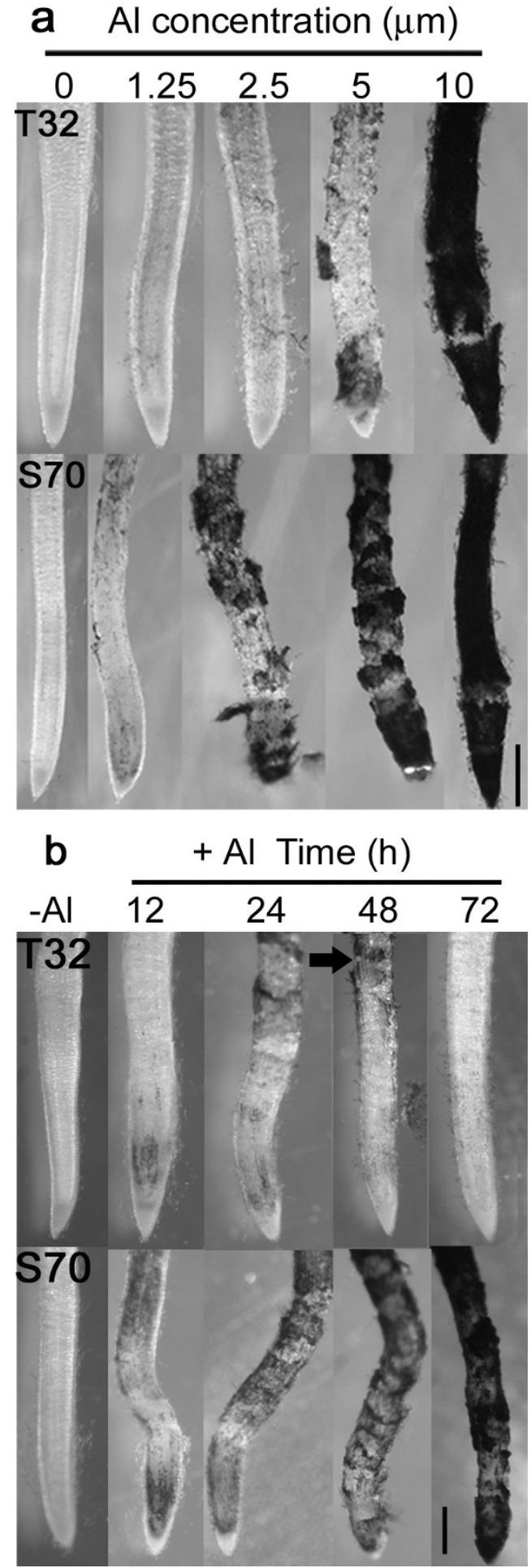

Figure 3

Al-accumulation in $M$. truncatula root apices. (a) Hematoxylin staining of T32 and S70 seedlings exposed to a range of Al concentrations for $48 \mathrm{~h}$. (b) Hematoxylin staining of root apices of $M$. truncatula grown in $2.5 \mu \mathrm{M}$ Al solution for 0 to $72 \mathrm{~h}$. Scale bar represents $500 \mu \mathrm{m}$. 
cal threshold were identified as significantly up- or downregulated in Al-treated roots. In addition, we used a 2-fold change cut-off for the significant genes. Normalized and raw data have been submitted to NCBI Gene Expression Omnibus (Accession No. GSE6946). In both lines, the expression of a majority of transcripts appeared unchanged at both time points with $\mathrm{Al}$ treatment. As shown in Figure 4, more genes were significantly altered by $\geq 2.0$-fold in $12 \mathrm{~h} \mathrm{Al-treated} \mathrm{root} \mathrm{tips} \mathrm{compared} \mathrm{to} 48$ h Al-treated root tips. Additionally, at both time points, a greater number of Al-induced genes were observed in S70 root tips $(12 \mathrm{~h}=365 ; 48 \mathrm{~h}=287)$. Since root growth of S70 was inversely correlated with $\mathrm{Al}$ accumulation at these time points, the greater number of up-regulated genes in S70 at both time points likely corresponds to greater $\mathrm{Al}$ stress perception and may reflect $\mathrm{Al}$ toxicity responses. In contrast, the numbers of down-regulated genes were similar in both lines and at both time points (Figure 4). It has been suggested that adaptive reprogramming to stressful conditions may require a higher number of down-regulated genes [40]; therefore, the similar numbers of downregulated genes at both time points in both lines might reflect an overlap in Al stress adaptation responses.
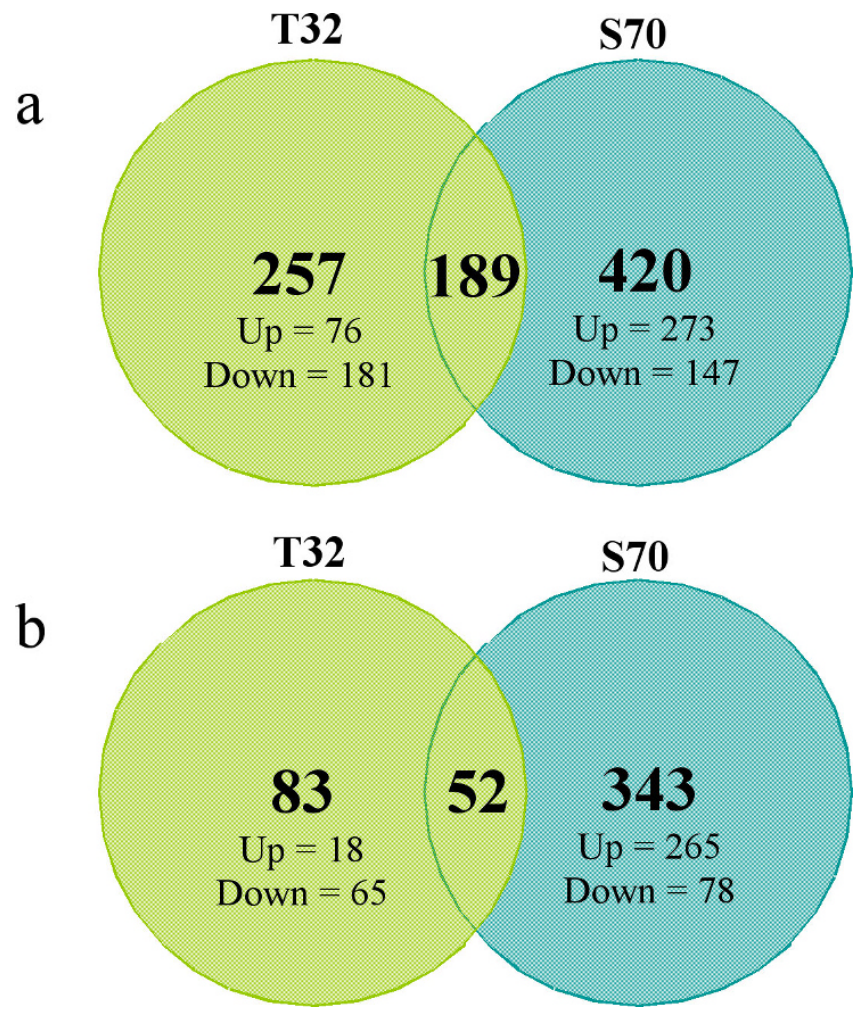

Figure 4

Genes with significantly altered expression in Altreated root tips compared to control root tips in T32 and S70. (a) $12 \mathrm{~h} \mathrm{Al} \mathrm{treatment.} \mathrm{(b)} 48 \mathrm{~h} \mathrm{Al} \mathrm{treatment.}$
The genes showing significantly different transcript accumulation patterns in response to $\mathrm{Al}$ in $\mathrm{T} 32$ and $\mathrm{S} 70$ experiments were further compared to determine the number that were up- or down-regulated in response to Al treatment by 2 -fold or more in both lines vs. only in one line (Figure 4). At the $12 \mathrm{~h}$ time point, 257 genes were uniquely expressed in T32 and 420 in S70. By 48 h T32 had 83 uniquely expressed genes and 343 were expressed only in S70. These differences may represent differences in $\mathrm{Al}$ stress perception and adaptation in T32 and S70 root tips. The large number of shared genes at the $12 \mathrm{~h}$ time point (189) might reflect an overlap in the Al toxicity responses in both lines. A list of selected significant differentially regulated genes is presented in Table 2. Functional categorization for all genes was based on Gene Ontology (GO) process information http://www.geneontology.org.

The Al-regulated expression changes in 12 significant genes were examined for both lines by quantitative reverse-transcription PCR (q-PCR). The q-PCR results showed the same direction of fold change of transcript abundance as the microarray in all three biological replicates for most genes (Table 3). In most cases, expression ratios based on q-PCR were higher than those ratios obtained from microarray hybridizations. This difference in expression ratios estimated by the two techniques has been observed previously [41] and reflects the specificity and sensitivity of the q-PCR technique [42]. The ratios (T32/S70) of the mean q-PCR fold change values were similar to the ratios of the microarray fold change values for most genes tested, thereby validating the microarray results.

\section{Gene expression in response to $\mathbf{I} \mathrm{h}$ of Al treatment in $\mathbf{S 7 0}$ root tips}

After $12 \mathrm{~h}$ of Al treatment, the RRG of S70 was approximately $45 \%$ (Figure $2 \mathrm{~b}$ ) with $\mathrm{Al}$ accumulating mainly in the epidermis and outer cortical cells of the root tip (Figure 5). Aluminum has been shown to rapidly bind to the pectic matrix in the cell wall, reduce cell wall (CW) extensibility $[7,43]$, and consequently inhibit root elongation. Thus, as might be expected, a number of CW-related genes potentially involved in CW loosening including a pectinesterase precursor, an expansin-like protein and a xyloglucan endotransglycosylase, were differentially regulated in response to Al treatment in S70 root tips (Table 2). Pectin methylesterases have been shown to increase the $\mathrm{Al}$ sensitivity of plants because their ability to demethylate pectin, in addition to altering the sensitivity of the CW to the action of other CW-degrading enzymes [44], might create additional binding sites for $\mathrm{Al}$ in the $\mathrm{CW}$ $[45,46]$. This can occur by increasing the free organic acid moieties (in galacturnoic acid) in the wall, making it more negatively charged. Recently, we showed that the downregulation of a pectin acetylesterase gene in M. truncatula 
Table 2: Selected genes differentially regulated by $\geq \mathbf{2 . 0}$-fold or $\leq \mathbf{0 . 5}$-fold in at least one $M$. truncatula line in response to $\mathbf{A l}$ treatment.

\begin{tabular}{|c|c|c|c|c|c|c|}
\hline \multirow[t]{2}{*}{ TIGR TC } & \multirow{2}{*}{$\begin{array}{l}\text { Tentative Annotation } \\
\text { Cell Wall Modification }\end{array}$} & \multirow[t]{2}{*}{ GO process iD } & \multicolumn{2}{|c|}{ Fold Change T32 } & \multicolumn{2}{|c|}{ Fold Change S70 } \\
\hline & & & $12 \mathrm{~h}$ & $48 \mathrm{~h}$ & $12 \mathrm{~h}$ & $48 \mathrm{~h}$ \\
\hline TC96658 & Xyloglucan endotransglucosylase putative & Carbohydrate metabolism GO:0005975 & 2.2 & 2.9 & 5.3 & 10.7 \\
\hline TCI00486 & Xyloglucan endotransglycosylase putative & Carbohydrate metabolism & 2.3 & 0.9 & 1.3 & 0.8 \\
\hline TC95073 & Polygalacturonase like protein & Carbohydrate metabolism & 2.6 & 0.6 & 4.3 & 1.3 \\
\hline TC96355 & Polygalacturonase & Carbohydrate metabolism & I.I & 2.3 & ND & 4.1 \\
\hline TCIII920 & Polygalacturonase PGI putative & Carbohydrate metabolism & 1.4 & 2.8 & 1.5 & 3.7 \\
\hline TCI 10038 & Pectinesterase putative & Cell wall modification GO:0042545 & 2.0 & 1.1 & 1.3 & 0.7 \\
\hline TC94920 & Probable pectinesterase precursor & Cell wall modification & 2.2 & 0.8 & 4.5 & ND \\
\hline TCI07655 & Xyloglucanase inhibitor putative & Unknown & 1.3 & 1.3 & 4.4 & ND \\
\hline TC94309 & Xyloglucanase inhibitor putative & Unknown & I.I & 0.9 & 2.0 & 0.9 \\
\hline TC94310 & Xyloglucanase inhibitor putative & Unknown & I.I & 0.8 & 2.1 & 0.9 \\
\hline TC98964 & Caffeic acid O-methyltransferase & Lignin biosynthesis GO:0009809 & 1.3 & 0.9 & 1.5 & 2.0 \\
\hline TCI07848 & Caffeic acid O-methyltransferase II & Lignin biosynthesis & 1.2 & 1.2 & 2.1 & 1.3 \\
\hline TCI00394 & Caffeic acid O-methyltransferase & Lignin biosynthesis & 1.1 & ND & 2.1 & 2.8 \\
\hline TC94484 & Expansin & Cell expansion GO:000983I & 1.5 & 1.5 & 2.0 & 3.7 \\
\hline TCI09283 & Expansin & Cell expansion & 1.4 & 1.5 & 1.4 & 3.0 \\
\hline TCI00685 & Pectate lyase & Unknown & 1.4 & 1.8 & 1.2 & 4.7 \\
\hline TC96079 & Pectate lyase & Unknown & 1.4 & 1.8 & 1.9 & 4.6 \\
\hline TCI08882 & $\beta$-I,4-glucanase & Carbohydrate metabolism & 1.3 & 1.5 & ND & 10.6 \\
\hline TCI08539 & Arabinogalactan protein-like & Cell adhesion GO:0007I55 & 0.6 & 1.1 & $1.0^{\text {ns }}$ & 3.8 \\
\hline TC94068 & Fasciclin-like AGP I4 & Cell adhesion & ND & 1.1 & 1.0 & 2.3 \\
\hline TCI08519 & Fasciclin-like AGP I4 & Cell adhesion & 0.6 & 1.5 & ND & 6.9 \\
\hline \multirow[t]{2}{*}{ TCI04866 } & Pectinesterase like protein & Cell wall modification & 0.5 & 1.3 & 0.3 & 0.5 \\
\hline & Oxidative Stress-ROS Generation & & & & & \\
\hline TC95I54 & Peroxidase & Response to oxidative stress GO:0006979 & 6.3 & 3.9 & 16.4 & 3.0 \\
\hline TCI0358I & Peroxidase & Response to oxidative stress & 5.2 & 2.5 & 9.9 & 2.6 \\
\hline TCI08789 & Peroxidase II precursor & Response to oxidative stress & 4.2 & 3.5 & 7.6 & 2.4 \\
\hline TC97623 & Peroxidase & Response to oxidative stress & 2.6 & 3.1 & ND & 0.7 \\
\hline TCI07670 & Peroxidase & Response to oxidative stress & 3.0 & 1.6 & 4.3 & 1.3 \\
\hline TCI08447 & Peroxidase 2 & Response to oxidative stress & 2.9 & 0.4 & 2.3 & 0.8 \\
\hline TC95I64 & Peroxidase 55 precursor & Response to oxidative stress & 2.0 & 0.9 & 3.2 & 1.9 \\
\hline TCIII928 & Peroxidase precursor & Response to oxidative stress & 1.6 & 2.9 & 2.4 & 2.8 \\
\hline TCI03214 & Peroxidase & Response to oxidative stress & $\mathrm{I} .4$ & 0.7 & 1.4 & 2.4 \\
\hline TCI01009 & Peroxidase & Response to oxidative stress & 1.6 & 0.9 & ND & 2.8 \\
\hline TCI083I5 & Cationic peroxidase 2 precursor & Response to oxidative stress & I.I & 0.9 & 1.9 & 2.7 \\
\hline TCIII87I & Peroxidase & Response to oxidative stress & $\mathrm{I} .4$ & 1.4 & 2.4 & 2.3 \\
\hline TC94676 & Peroxidase precursor & Response to oxidative stress & 1.2 & 1.2 & 2.2 & 2.5 \\
\hline TCI08988 & Germin-like protein precursor & Response to oxidative stress & 2.9 & ND & 1.6 & 0.5 \\
\hline TCI00563 & Germin-like protein & Response to oxidative stress & 1.6 & ND & 2.3 & 1.1 \\
\hline TC94265 & Germin-like protein & Response to oxidative stress & 0.9 ns & 0.6 & 2.1 & $1.9 \mathrm{~ns}$ \\
\hline TC107416 & Carbohydrate oxidase & Electron transport GO:0006। I8 & 1.2 & 1.4 & 4.3 & 1.7 \\
\hline TCI03024 & Peroxidase & Response to oxidative stress & 0.4 & 0.3 & 0.4 & 0.1 \\
\hline TCI00904 & Peroxidase precursor & Response to oxidative stress & 0.2 & 0.2 & 0.1 & 0.2 \\
\hline TCI02226 & Peroxidase & Response to oxidative stress & 0.3 & ND & 0.1 & 0.2 \\
\hline TCI04806 & Probable peroxidase & Response to oxidative stress & 0.4 & 0.3 & 1.5 & 0.4 \\
\hline TCI0685I & Peroxidase 2 & Response to oxidative stress & 0.4 & 0.5 & 0.6 & 0.5 \\
\hline TCI08234 & Peroxidase precursor & Response to oxidative stress & 0.2 & 0.3 & 0.2 & 0.7 \\
\hline TC968I7 & Germin-like protein & Response to oxidative stress & $0.5^{\text {ns }}$ & 1.4 & 0.3 & 0.8 \\
\hline TCI00I75 & Lipoxygenase & Jasmonic acid biosynthesis GO:0009695 & 0.4 & 0.4 & ND & 1.1 \\
\hline $\mathrm{TCl} 00188$ & Lipoxygenase LoxN2 & Jasmonic acid biosynthesis & 0.7 & 0.5 & 0.5 & 0.9 \\
\hline TCI00I55 & Lipoxygenase & Jasmonic acid biosynthesis & 0.6 & 0.3 & 0.5 & 0.7 \\
\hline \multirow[t]{2}{*}{$\mathrm{TC} 100171$} & Lipoxygenase & Jasmonic acid biosynthesis & 0.6 & 0.3 & 0.5 & 0.8 \\
\hline & Oxidative Stress- ROS Scavenging & & & & & \\
\hline TC94929 & Quinone-oxidoreductase QRI & Threonine catabolism GO:0006567 & 2.0 & 1.2 & 1.8 & $0.9^{\text {ns }}$ \\
\hline TCII 0730 & Quinone-oxidoreductase QRI & Threonine catabolism & 2.2 & 1.3 & 1.3 & 0.8 \\
\hline TCI07874 & NADH-ubiquinone oxidoreductase & Electron transport & I.Ins & 2.3 & 0.3 & 0.8 \\
\hline
\end{tabular}


Table 2: Selected genes differentially regulated by $\geq \mathbf{2 . 0}$-fold or $\leq \mathbf{0 . 5}$-fold in at least one $M$. truncatula line in response to Al treatment.

\begin{tabular}{ll}
\hline TC95262 & Blue copper protein precursor \\
TC103046 & Thioredoxin-like 4 \\
TC96215 & Thioredoxin H2 \\
TC104708 & Thioredoxin H2 \\
TC104047 & Thioredoxin 3 \\
BM8I3626 & Ascorbate peroxidase \\
TCI01862 & Alternative oxidase 3 \\
TC95582 & Tyrosine aminotransferase \\
TCI008I5 & 4-hydroxyphenylpyruvate dioxygenase \\
TC108214 & Glutathione S-transferase GST 5 \\
TC100556 & Glutathione-S-transferase \\
TCI05598 & Probable glutathione S-transferase \\
TC95231 & Probable glutathione S-transferase \\
TCI06943 & Glutathione S-transferase GST 8 \\
TC94362 & Glutathione S-transferase GST 8 \\
TC106973 & Glutathione S-transferase \\
TC95247 & Glutathione S-transferase GST I4 \\
TC95380 & Glutathione S-transferase GST I5 \\
TCI088I7 & Glutathione S-transferase GST II
\end{tabular}

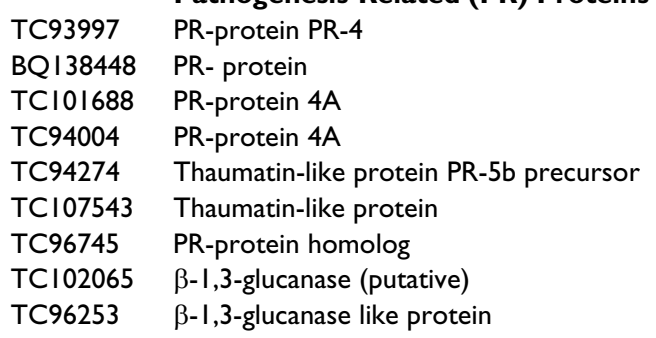

TC96253 $\beta$-I,3-glucanase like protein

$\begin{array}{ll}\text { TC9493I } & \begin{array}{l}\text { Isoflavonoid Biosynthesis } \\ \text { Cytochrome P450 }\end{array} \\ \text { TC101508 } & \text { Isoflavone 2'-hydroxylase } \\ \text { TC95424 } & \text { Isoflavone 3'-hydroxylase } \\ \text { TC96039 } & \text { Isoflavone reductase related protein } \\ \text { TC106939 } & \text { Isoflavone synthase putative } \\ \text { TC97999 } & \text { Cytochrome P450 monooxygenase }\end{array}$

ABA-responsive protein-like

TCl08387 Abscisic acid-responsive protein

TCI06508 Abscisic stress ripening protein homolog

BG4540I8 Late embryogenesis abundant protein

TC94387 Late embryogenesis abundant protein 2

TC94389 Late embryogenesis abundant protein 2

TC94508 Seed maturation protein LEA 4

TCI0I5I9 Patatin-like protein I

TCI0I298 Glucosyl transferase

TC94863 Glucosyltransferase putative

TCI00689 Glucosyltransferase-6

TCII0504 Glucosyltransferase-7

TCI03I47 Tumor-related protein

TCI07043 ER6 protein (universal stress protein)

$\mathrm{TCl} 10393$ Heavy metal domain containing protein

TCl03767 Universal stress protein

TC95896 Dehydration responsive element binding

TCI10815 AP2 domain transcription factor

TCIII 267 Probable WRKY transcription factor 23

TCI02282 Probable WRKY transcription factor 28

TCI0176I Putative WRKY4 transcription factor

TC97324 WRKY-type DNA binding protein

TCI03586 ZPT2
Electron transport

Electron transport

Electron transport

Electron transport

Electron transport

Response to oxidative stress

Alternative respiration GO:0010230

Vitamin $\mathrm{E}$ biosynthesis GO:0010189

Vitamin $\mathrm{E}$ biosynthesis

Response to oxidative stress

Response to oxidative stress

Response to oxidative stress

Response to oxidative stress

Response to oxidative stress

Response to oxidative stress

Response to oxidative stress

Response to oxidative stress

Response to oxidative stress

Response to oxidative stress

Defense response GO:0006952
Defense response
Defense response
Defense response
Response to pathogen GO:0042828
Response to pathogen
Defense response
Carbohydrate metabolism
Carbohydrate metabolism

Electron transport

Electron transport

Electron transport

Response to oxidative stress

Electron transport

Electron transport

Response to desiccation GO:0009269
Response to desiccation
Response to desiccation
Response to desiccation
Response to desiccation
Response to desiccation
Response to desiccation
Lipid metabolism GO:0006629
Metabolism GO:0008152
Metabolism
Metabolism
Metabolism
Unknown

Response to stress GO:0006950

Metal ion transport GO:003000 I

Response to stress

Regulation of transcription GO:0006355

Regulation of transcription

Regulation of transcription

Regulation of transcription

Regulation of transcription

Regulation of transcription

Regulation of transcription GO:0045449

$\begin{array}{lccc}3.1 & 1.6 & 1.9 & 1.3^{\text {ns }} \\ 2.1 & 1.3 & 5.3 & 1.8 \\ 0.6 & 2.4 & 0.4 & 0.7 \\ \text { ND } & 2.4 & 1.3^{\text {ns }} & 3.0 \\ 0.9 & 2.3 & 0.8 & 3.8 \\ 0.7 & 0.9 & 1.6 & 2.6 \\ 1.3 & 0.8 & 1.7 & 2.0 \\ 1.5 & 2.5 & 8.3 & \text { ND } \\ 1.2 & 1.1 & 2.3 & 1.3 \\ 2.2 & \text { ND } & 1.4 & 1.4 \\ 2.2 & 1.1 & 2.3 & \text { ND } \\ 1.3 & 1.4 & 2.3 & 1.0^{\text {ns }} \\ 1.3 & 1.0 & 2.1 & 0.8 \\ 1.3 & 1.0 \text { ns } & 2.1 & \text { ND } \\ 1.2 & 1.2 & 2.0 & 1.0 \\ 1.1 & 1.3 & 3.3 & \text { ND } \\ 1.0^{\text {ns }} & 0.7 & 2.2 & 0.2 \\ \text { ND } & 1.2 & 0.5 & 0.8 \\ \text { ND } & 1.7 & 0.7 & 0.4\end{array}$

2.6

ND

0.6

0.6

1.3

1.6

1.5

\section{7}

$\begin{array}{ll}5.0 & 2.1 \\ 2.3 & 3.2 \\ 2.7 & 1.4 \\ 2.7 & 1.6 \\ 2.1 & 1.8 \\ 2.7 & 1.9 \\ 1.6 & 2.4 \\ 2.3 & 3.0 \\ 2.0 & 0.9\end{array}$

2.5

1.6

1.8

1.8

1.3

1.2

1.4

$1.0^{\mathrm{ns}}$

$$
0.9
$$

0.9

ND

0.9

$\begin{array}{lc}2.2 & 1.6^{\mathrm{ns}} \\ 2.6 & 1.5 \\ 3.8 & \mathrm{ND} \\ 3.1 & 1.2 \\ 2.2 & 1.0^{\mathrm{ns}} \\ 2.1 & 1.4\end{array}$

$\begin{array}{llll}1.7 & 1.4 & 2.7 & 1.3\end{array}$

1.8

1.3

5.5

1.5

1.8

1.9

3.6

0.5

1.6

1.6

1.4

0.5

0.3

0.6

I.Ins

1.6

I.I

1.5

1.6

1.3

1.8

2.9

$\begin{array}{ccc}1.4 & 2.7 & 1.3 \\ 1.2 & 2.5 & 2.0 \\ 1.3 & 2.6 & 2.7 \\ 0.8^{\text {ns }} & 12.9 & 1.2 \\ 1.1 & 4.2 & 0.9 \\ 1.2 & 5.1 & 0.9 \\ 1.0 & 4.6 & 0.9 \\ 0.7 & 6.6 & 0.5 \\ 0.6 & 2.0 & \mathrm{ND} \\ 0.8 & 2.3 & \mathrm{ND} \\ 1.5 & 2.0 & 1.5 \\ 1.4 & 6.3 & \mathrm{ND} \\ 0.7 & 2.3 & 4.2 \\ 1.2 & 0.7 & 2.8 \\ 0.9 & 0.9 \text { ns } & 4.0 \\ 0.8 & 1.4 & 3.1 \\ \mathrm{ND} & 3.5 & 0.7 \\ 1.2 & 2.4 & 0.9 \text { ns } \\ 1.3 & 2.4 & 1.4 \\ 1.4 & 2.0 & 1.3^{\text {ns }} \\ \mathrm{I} .0^{\text {ns }} & 3.2 & 1.2 \\ \mathrm{I} .3 & 3.5 & 0.9 \\ \mathrm{ND} & 3.5 & \mathrm{ND}\end{array}$


Table 2: Selected genes differentially regulated by $\geq \mathbf{2 . 0}$-fold or $\leq \mathbf{0 . 5}$-fold in at least one $M$. truncatula line in response to Al treatment.

\begin{tabular}{|c|c|c|c|c|c|c|}
\hline & Cell Death & & & & & \\
\hline TCI0377I & Ethylene up-regulated gene ER66 & Ethylene signaling pathway GO:0009873 & 2.6 & 1.2 & 3.8 & 2.3 \\
\hline TCI05302 & Subtilisin-like proteinase & Proteolysis and peptidolysis GO:0006508 & 2.4 & 1.3 & 1.9 & 1.4 \\
\hline TC95356 & probable serine proteinase & Proteolysis and peptidolysis & 2.3 & $1.1^{\text {ns }}$ & 1.8 & 1.3 \\
\hline TCI03618 & Subtilisin-like protease & Proteolysis and peptidolysis & 2.3 & 1.2 & 1.8 & 1.2 \\
\hline TCI0326I & Papain-like cysteine proteinase & Proteolysis and peptidolysis & 2.8 & 0.9 & 4.7 & ND \\
\hline TCI0II94 & TINI5.5 & Apoptosis GO:0006915 & 2.0 & 1.1 & 1.5 & 0.9 \\
\hline $\mathrm{TCI} 12103$ & Subtilisin-type protease & Proteolysis and peptidolysis & 1.8 & 0.9 & $\mathrm{I} . \mathrm{I}^{\mathrm{ns}}$ & 2.3 \\
\hline TC107719 & Putative cell death associated protein & Unknown & 0.9 & 1.1 & 0.8 & 2.2 \\
\hline TCI07I53 & Cystatin & Cysteine protease inhibitor GO:0004869 & 1.8 & 1.2 & 2.4 & 1.3 \\
\hline TC94966 & Cystatin & Cysteine protease inhibitor & 0.4 & $0.9^{\text {ns }}$ & 0.4 & 1.6 \\
\hline \multirow[t]{2}{*}{$\mathrm{B} \mid 310700$} & Cystatin & Cysteine protease inhibitor & 0.4 & 1.0 & 0.4 & 1.7 \\
\hline & Senescence & & & & & \\
\hline $\mathrm{TCl} 01276$ & Rhodanese-like family protein & Aging GO:0007568 & 2.3 & 1.4 & 2.0 & ND \\
\hline TCI01956 & Senescence-associated protein sen I & Aging & 2.1 & 0.8 & 5.2 & 1.3 \\
\hline TCI07982 & Probable senescence-related protein & Aging & 1.2 & ND & 3.4 & 1.5 \\
\hline TCI07460 & Ntdin & Aging & 1.4 & I.I & 2.1 & 1.3 \\
\hline TC94722 & Putative senescence-associated protein & Aging & 0.1 & 1.8 & 0.3 & 5.6 \\
\hline \multirow[t]{2}{*}{ TCI07766 } & SRGI protein & Aging & 0.8 & 0.4 & 0.8 & 0.8 \\
\hline & Unknown/Miscellaneous & & & & & \\
\hline TCI05342 & MATE & Unknown & 39.8 & 33.9 & 51.3 & 23.7 \\
\hline $\mathrm{TCl} 102211$ & GAST-I protein precursor & Response to gibberellic acid stimulus & 2.2 & 2.1 & 1.9 & 1.3 \\
\hline TCIII698 & COBRA-like gene & Unknown & 16.3 & 1.7 & 18.8 & ND \\
\hline TC95697 & F-box protein & Unknown & 5.0 & $1.1^{\text {ns }}$ & 1.4 & ND \\
\hline TCI08263 & E3 ubiquitin ligase SCF complex & Protein catabolism GO:00065II & 2.2 & 1.4 & 1.7 & 1.5 \\
\hline
\end{tabular}

TIGR TC, The Institute for Genomic Research Tentative Consensus sequence ID version 8.0; Tentative Annotation, based on TIGR/NCBI tBLASTx tool; GO = Gene Ontology; Fold Change = ratio of transcript abundance in Al treatment/transcript abundance in control $(-\mathrm{Al})$ treatment; ns = not significant; ND = not detected.

transgenic roots resulted in a modest increase $(\sim 20 \%)$ in root growth under $\mathrm{Al}$ stress conditions compared to wildtype plants [31]. Based on these results it appears that plant cells respond to Al-induced CW stiffening by enhancing the expression of CW loosening enzymes in an attempt at stimulating CW expansion.

Notable at this time point was the accumulation of gene transcripts encoding reactive oxygen species (ROS) generating enzymes. Genes encoding peroxidases and peroxidase precursors as well as germin-like proteins and carbohydrate oxidase were up-regulated (Table 2). Aluminum toxicity has previously been shown to trigger the expression and activity of ROS generating enzymes and ROS accumulation has been shown to positively correlate with $\mathrm{Al}$ sensitivity $[47,48]$. ROS are capable of causing oxidative damage to proteins, DNA, and lipids in plant cells and may ultimately lead to cell death [49]. The enhanced expression of genes encoding ROS generating enzymes suggest that upon $\mathrm{Al}$ stress, $\mathrm{S} 70$ root tips experience oxidative damage, which could in turn result in complete root growth inhibition (Figure 2b). A number of genes coding for ROS generating enzymes were also found to be downregulated in $\mathrm{S} 70$ at $12 \mathrm{~h}$ of Al treatment (Table 2). It is possible that specific peroxidases may be involved in the $\mathrm{Al}$ toxicity response, consequently resulting in the down-regulation of peroxidases involved in other responses, including ones that might be involved in ROS scavenging.

The observed increase in transcript accumulation of ROS generating genes may reflect ROS accumulation in root tips and therefore may elicit the expression of antioxidantrelated genes. Consistent with this hypothesis, an increase in the expression of antioxidant genes was observed in S70 root tips. Genes putatively encoding glutathione Stransferase and thioredoxin were significantly up-regulated (Table 2). Also up-regulated were genes encoding tyrosine aminotransferase and 4-hydroxyphenylpyruvate dioxygenase, enzymes involved in the biosynthesis of $\alpha$ tocopherols, which function as membrane stabilizers and antioxidants that scavenge oxygen free radicals, lipid peroxy radicals, and singlet oxygen [50].

A number of stresses induce production of ROS and lipid peroxidation, including pathogen attack. Since $\mathrm{Al}$ resulted in accumulation of ROS generating gene transcripts in $\mathrm{S} 70$ root tips, the resulting ions and oxidative damage might have triggered the up-regulation of a number of pathogen defense-related and membrane-stabilizing genes (Table 2). A number of genes encoding isoflavonoid biosynthetic 
Table 3: Real-time PCR validation of microarray results.

\begin{tabular}{|c|c|c|c|c|c|c|c|c|}
\hline \multirow[b]{2}{*}{ TIGR TC } & \multirow[b]{2}{*}{ Annotation } & \multirow[b]{2}{*}{ Time (h) } & \multirow[b]{2}{*}{ M. truncatula line } & \multirow[b]{2}{*}{ Microarray fold change } & \multicolumn{2}{|c|}{ qPCR fold change } & \multicolumn{2}{|c|}{ Ratio (T32/S70) } \\
\hline & & & & & Mean & SE & Array & qPCR \\
\hline \multirow[t]{2}{*}{ TCI05342 } & MATE & 12 & T32 & 39.8 & 44.0 & 7.8 & 0.8 & 0.7 \\
\hline & & & S70 & 51.3 & 67.4 & 6.4 & & \\
\hline \multirow[t]{2}{*}{ TC95697 } & F-box protein & 12 & T32 & 5.0 & 13.7 & 4.0 & 3.6 & 4.4 \\
\hline & & & S70 & 1.4 & 3.1 & 0.2 & & \\
\hline \multirow[t]{2}{*}{ TCI03586 } & ZPT-2 & 12 & T32 & 2.9 & 2.4 & 0.2 & 0.8 & 0.4 \\
\hline & & & S70 & 3.5 & 6.1 & 0.9 & & \\
\hline \multirow[t]{2}{*}{ TCIII698 } & COBRA-like gene & 12 & T32 & 16.3 & 24.7 & 0.6 & 0.9 & 0.5 \\
\hline & & & S70 & 18.8 & 53.7 & 16.4 & & \\
\hline \multirow[t]{2}{*}{ TC93997 } & PR-protein PR-4 & 12 & T32 & 2.6 & 2.5 & 0.3 & 0.5 & 0.5 \\
\hline & & & S70 & 5.0 & 5.0 & 1.1 & & \\
\hline \multirow[t]{2}{*}{ TCI00486 } & Xyloglucan endotransglycosylase & 12 & T32 & 2.3 & 2.2 & 0.1 & 1.8 & 1.6 \\
\hline & & & S70 & 1.3 & 1.4 & 0.3 & & \\
\hline \multirow[t]{2}{*}{ TC96658 } & Xyloglucan endotransglycosylase & 48 & T32 & 2.9 & 3.7 & 1.0 & 0.3 & 0.1 \\
\hline & & & S70 & 10.7 & 38.3 & 5.6 & & \\
\hline \multirow[t]{2}{*}{$\mathrm{TCl} 02211$} & GAST-I & 48 & T32 & 2.1 & 7.2 & 0.4 & 1.6 & 0.3 \\
\hline & & & S70 & 1.3 & 25.8 & 5.7 & & \\
\hline \multirow[t]{2}{*}{ TCIII920 } & Polygalacturonase PGI putative & 48 & T32 & 2.8 & 2.5 & 0.2 & 0.8 & 0.6 \\
\hline & & & S70 & 3.7 & 4.0 & 0.5 & & \\
\hline \multirow[t]{2}{*}{ TCI0377I } & Ethylene up- regulated gene ER66 & 48 & T32 & 1.2 & 1.3 & 0.2 & 0.5 & 0.3 \\
\hline & & & S70 & 2.3 & 4.6 & 0.8 & & \\
\hline \multirow[t]{2}{*}{ TC95I54 } & Peroxidase & 48 & T32 & 3.9 & 1.2 & 0.1 & 1.3 & 0.4 \\
\hline & & & S70 & 3.0 & 2.9 & 0.1 & & \\
\hline \multirow[t]{2}{*}{ TCI00I55 } & Lipoxygenase & 48 & T32 & 0.5 & 0.4 & 0.0 & 0.7 & 0.6 \\
\hline & & & S70 & 0.7 & 0.6 & 0.1 & & \\
\hline
\end{tabular}

enzymes were uniquely up-regulated in $12 \mathrm{~h}$ Al-treated S70 root tips (Table 2). The isoflavonoids, which are mostly limited to the subfamily Papilionoideae of the Fabaceae, have been shown to function as phytoalexins [51] and antioxidants [52]. Their up-regulation in response to $\mathrm{Al}$ stress may represent a unique response of the legume family to Al-induced oxidative stress.

It has been shown that ROS triggers cell death by apoptosis, necrosis, or mechanisms with features of both [53]. Between 24 and $48 \mathrm{~h}$ of $\mathrm{Al}$ treatment, cell death of Alaccumulating epidermal and outer cortical cell layers was observed in S70 root tips. Fluorescence observed in root tip cells as a result of morin staining depicts Al-accumulation while both light microscopy of Al-treated root tip cross sections (Figure 5) and root tips stained with Evan's blue, which is a dye that measures extent of cell death, indicates cell death (Figure 6). Consistent with this phenotypic observation, a number of cell-death associated genes were up-regulated in S70 root tips including cysteine proteinase, senescence associated proteins and genes for $\mathrm{CW}$ degrading enzymes that may be necessary for cell separation during programmed cell death. Hypothetically, gene expression data from S70 root tips after 12 $\mathrm{h}$ of Al treatment reflects enhanced CW stiffening, severe oxidative damage probably due to significant ROS accumulation and activation of cell death.

\section{Gene expression in response to $48 \mathrm{~h}$ of Al treatment in $\mathbf{S 7 0}$ root tips}

After $48 \mathrm{~h}$ of Al treatment, RRG of S70 was approximately $17 \%$ (Figure 2b). Notably, transcript accumulation of $\mathrm{CW}$-modifying genes was observed at this time point (Table 2) suggesting continued $\mathrm{CW}$ stiffening from $\mathrm{Al}$ treatment. Furthermore, the prolonged induction of caffeic acid O-methyltransferase, involved in lignin biosynthesis only in S70 root tips could contribute to continued Al-induced root elongation inhibition. Genes putatively encoding polygalacturonase, pectate lyases, and $\beta-1,4$ glucanase, which are CW-degrading enzymes, were significantly up-regulated in S70 root tips (Table 2). It is plausible that cell separation during the persistent cell death response at $48 \mathrm{~h}$ of $\mathrm{Al}$ treatment may elicit the prolonged expression of these genes. Interestingly, three genes encoding putative arabinogalactan-proteins (AGP) were uniquely up-regulated in S70 at $48 \mathrm{~h}$ of Al treatment. AGPs belong to a class of hydroxyproline-rich glycoproteins that are abundant in the plant $\mathrm{CW}$ and membrane [54], with no clear function. Two maize AGPs were found in disintegrating xylem cells and a role in identifying cells committed to PCD was proposed [55]. Furthermore, two AGP genes were identified as showing enhanced expression in Arabidopsis after Al stress [56]. Thus, AGPs may represent a novel facet of the Al toxicity response since they are significantly up-regulated only in the Al-sensitive 


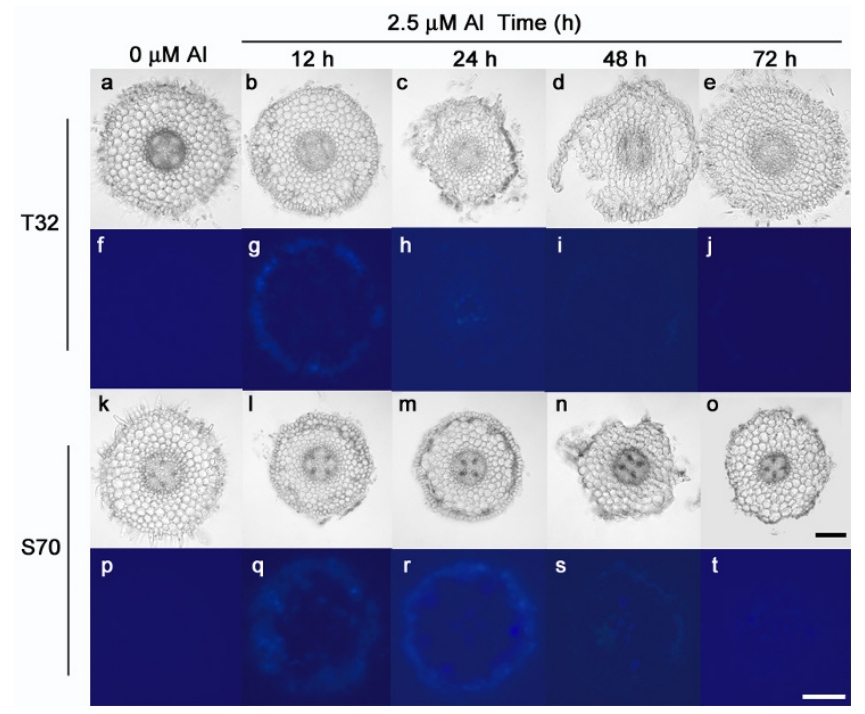

Figure 5

Effect of Al on surface cell layer morphology and localization of $\mathrm{Al}$ by morin in transverse sections taken $I .5$ to $2 \mathrm{~cm}$ behind root tips of $M$. truncatula lines. Smooth surface of transversal sections of T32 (a) and $\mathrm{S} 70(\mathrm{k})$ roots grown in $0 \mu \mathrm{M} \mathrm{Al}$ solution. Recovery from Alinduced damage as a result of new root growth in T32 root apices (b-e) exposed to $2.5 \mu \mathrm{M} \mathrm{Al}$ for 12, 24, 48 and $72 \mathrm{~h}$. Damaged outer epidermal and outer cortical cell layers as a result of no new root growth in $S 70$ root apices (I-O) exposed to $2.5 \mu \mathrm{M}$ Al. Black scale bar $=100 \mu \mathrm{m}$. Minimal background fluorescence observed in cells of T32 (f) and S70 (p) root apices grown in $0 \mu \mathrm{M}$ Al solution. Bright blue fluorescence indicates morin staining in cells of T32 $(g-j)$ and S70 (q- $\mathrm{t}$ ) root apices grown in $2.5 \mu \mathrm{M} \mathrm{Al}$ solution for I2, 24, 48 and $72 \mathrm{~h}$. White scale bar $=100 \mu \mathrm{m}$.

line and may be involved in modulating cell wall architecture and/or involved in the Al-induced cell death response.

Accumulation of transcripts for enzymes generating ROS remained high after $48 \mathrm{~h}$ of $\mathrm{Al}$ treatment. The maintenance of peroxidase transcripts up to $48 \mathrm{~h}$ of $\mathrm{Al}$ treatment is consistent with previous observations in tobacco cells [57] and Arabidopsis [29] in which these genes showed enhanced expression during prolonged Al treatments. A few antioxidant genes including thioredoxin, ascorbate peroxidase, and alternate oxidase were uniquely up-regulated in S70 root tips at $48 \mathrm{~h} \mathrm{Al}$ treatment. However, transcripts for other antioxidant related genes expressed after $12 \mathrm{~h}$ of Al treatment did not show enhanced accumulation at $48 \mathrm{~h}$. The enhanced expression of a greater number of ROS generating genes compared to antioxidant genes at $48 \mathrm{~h}$ suggests that the antioxidant capacity of S70 root tips might be insufficient to prevent significant ROS accumulation. Consequently, higher doses of ROS without suffi-

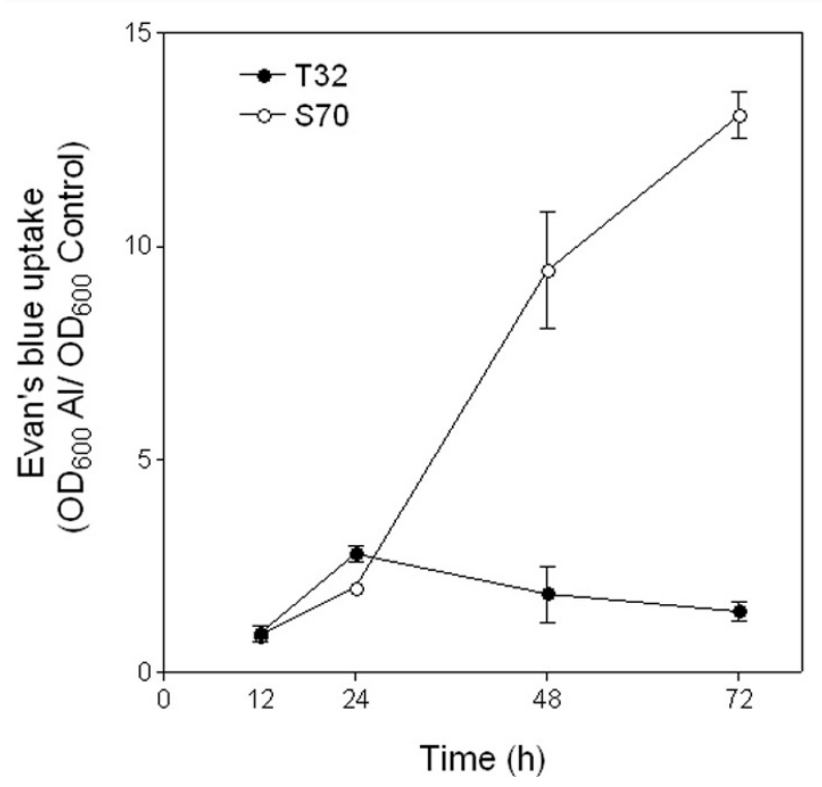

Figure 6

Measurement of cell death by Evans blue uptake in M. truncatula root apices. Relative Evans blue uptake $\left(O D_{600}\right.$ for $\mathrm{Al}$ treated root tips $/ \mathrm{OD}_{600}$ for control (-Al) root tips) in root tips of $M$. truncatula lines T32 and S70 grown in 0 $\mu \mathrm{M}$ and $2.5 \mu \mathrm{M} \mathrm{Al}$ solutions for $12,24,48$ and $72 \mathrm{~h}$.

cient scavenging, may lead to greater oxidative damage and necrosis in S70 root tips. Consistent with this hypothesis, the transcripts of four PR-genes and other stressrelated genes remained at elevated levels after $48 \mathrm{~h}$ of $\mathrm{Al}$ treatment suggesting continued oxidative damage. In addition, cell death and senescence-associated genes were uniquely up-regulated in $48 \mathrm{~h} \mathrm{Al-treated} \mathrm{S70} \mathrm{root} \mathrm{tips} \mathrm{sug-}$ gesting the longevity and severity of the cell death response. In agreement with the expression data, we observed $\mathrm{a} \geq 10$-fold extent of cell death in S70 Al-treated root tips compared to control root tips after $48 \mathrm{~h}$ of $\mathrm{Al}$ treatment (Figure 6). In addition, at these time points, $\mathrm{Al}$ was observed in some of the inner cortical layers of the root tip as indicated by morin staining (Figure 5).

Collectively, the prolonged expression of genes associated with CW loosening, ROS generation, cell death and CW degradation after $48 \mathrm{~h}$ of Al treatment implies that the Alinduced oxidative damage and cell death response resembles a necrotic response, damaging deeper cell layers and ultimately resulting in irreversible root growth inhibition in S70.

\section{Gene expression in response to $12 \mathrm{~h}$ Al treatment in T32 root tips}

At $12 \mathrm{~h}$ of Al treatment, the RRG of T32 was approximately $78 \%$ (Figure 2a) with $\mathrm{Al}$ accumulating mainly in 
the epidermal cell layer of the root tip as indicated by morin staining (Figure 5). The inhibition in root growth, although not as severe as in S70, might induce the expression of CW-related genes. Consistent with this hypothesis, $\mathrm{CW}$ loosening genes were similarly regulated in S70 and $\mathrm{T} 32$ root tips at $12 \mathrm{~h}$ of $\mathrm{Al}$ treatment (Table 2), indicating an overlap in responses to $\mathrm{Al}$ toxicity in both lines.

Transcript accumulation of genes encoding ROS generating enzymes in T32 root tips was similar to that observed in S70; however, the total number of up-regulated genes was lower in T32 root tips (Figure 4). A number of antioxidant genes accumulated similarly in both lines (Table 2). However, two quinone oxidoreductase genes, a glutathione s-transferase (GST) gene, and a blue copper protein (BCB) precursor were significantly up-regulated only in T32 root tips. Quinone-oxidoreductases, which are involved in the detoxification of reactive aldehydes derived from lipid peroxides [58] have previously been shown to be induced in response to $\mathrm{Al}$ treatment in Al-tolerant and Al-sensitive rice roots [59]. Previously, BCB and GST genes were shown to be up-regulated in Arabidopsis in response to $\mathrm{Al}$ treatment [29] and plants over-expressing these genes displayed increased resistance to low $\mathrm{Al}$ concentrations [60]. Therefore, these genes may represent a resistance response associated with ROS scavenging in response to $\mathrm{Al}$ treatment only in Al-resistant root tips. Relative to $\mathrm{S70}$, a greater number of ROS generating genes including peroxidases and peroxidase precursors were down-regulated in T32 (Table 2). However, in contrast to S70, antioxidant genes were not down-regulated in T32. In addition, up-regulation of fewer PR-genes, isoflavonoid biosynthetic genes, and stress-related genes (Table 2) reflected a lower extent of oxidative damage in T32 root tips. These data suggest that although there appears to be ROS accumulation in response to $12 \mathrm{~h} \mathrm{Al}$ treatment in T32 root tips, the levels may be lower than that observed in S70.

A number of cell-death associated genes were uniquely up-regulated in T32 after $12 \mathrm{~h}$ of Al treatment (Table 2). Expression of these genes is consistent with cell death observed at $24 \mathrm{~h}$ of Al treatment (Figure 5 and 6). Interestingly, cell death appeared to be restricted to cells that accumulate $\mathrm{Al}$ as visualized by light microscopy of root tip cross sections (Figure 5). It has been suggested that low Al concentration treatments induce cell death possibly via a ROS-activated signal transduction pathway [61]. However, exposure to more toxic concentrations of $\mathrm{Al}$ may cause necrosis in the root tip cells. Likewise, $\mathrm{H}_{2} \mathrm{O}_{2}$ produced in barley roots, during early phases of $\mathrm{Al}$ stress, has been suggested to play a role in the induction of cell death [62]. Therefore, in addition to the observed patterns of expression of ROS generating and scavenging genes, the activation of cell death in $\mathrm{Al}$-accumulating root tip cells indicate lower ROS accumulation in T32 after $12 \mathrm{~h} \mathrm{Al}$ treatment. Accumulation of low levels of ROS, which although might be insufficient to cause significant oxidative damage, may play a key role in triggering cell death of $\mathrm{Al}$-accumulating cells, as has been demonstrated in cell death responses to other abiotic and biotic stresses $[49,63]$.

\section{Gene expression in response to $48 \mathrm{~h}$ Al treatment in T32 root tips}

After $48 \mathrm{~h}$ of $2.5 \mu \mathrm{M} \mathrm{Al}$ treatment, the RRG of T32 recovered to approximately $90 \%$ (Figure 1 and $2 a$ ). At this time point fewer genes were differentially regulated in response to $\mathrm{Al}$ treatment in $\mathrm{T} 32$ root tips (Figure 4) compared to 12 $\mathrm{h}$ of treatment. Notably, fewer ROS generating genes were up-regulated, and up-regulation of a number of antioxidant genes was observed (Table 2). Since fewer ROS generating genes were up-regulated, the basal antioxidant capacity may have been sufficient to prevent significant ROS accumulation. Interestingly, there was no significant change in expression of stress-related genes, including PRproteins and isoflavonoids and cell death genes (Table 2) suggesting that the ROS levels may have been insufficient to cause oxidative damage and cell death. In fact, downregulation of some stress-related genes and senescenceassociated genes was observed at this time point (Table 2). Moreover, probably as a result of new root tip growth, the extent of Al accumulation and cell death at $48 \mathrm{~h}$ was minimal (Figure 5 and 6). Therefore, we speculate that in T32 root tips, the cell death response occurred early on and was aimed at removing $\mathrm{Al}$-accumulating cells leading to a recovery in root growth.

A continued response to $\mathrm{Al}$ stress in T32 root tips after 48 $\mathrm{h}$ of Al treatment was indicated by the high transcript accumulation of a putative multidrug and toxin extrusion (MATE) gene (TC105342; MtMATE). Although the expression of this gene was significantly up-regulated at both time points of $\mathrm{Al}$ treatment and in both lines (Table 2), the prolonged expression of this gene during root growth recovery in the Al-tolerant line made it an interesting candidate for $\mathrm{Al}$ resistance studies. We examined whether the spatial expression pattern of this gene played a role in differential Al resistance responses in these lines.

\section{Differential pattern of expression of MtMATE in T32 and S70}

To determine the spatial distribution of MATE gene expression in response to early $(3 \mathrm{~h})$ and later $(12 \mathrm{~h})$ time points of $\mathrm{Al}$ treatment, in situ PCR was carried out on root tip cross sections. In $3 \mathrm{~h} \mathrm{Al}$-treated T32 root tips, a positive signal was visible in cells of the endodermis and the regions encompassing the vascular bundles (Figure 7). In contrast, in $3 \mathrm{~h} \mathrm{Al-treated} \mathrm{S70} \mathrm{root} \mathrm{tips,} \mathrm{the} \mathrm{signal}$ appeared to be more uniformly distributed over the entire 
section including the epidermis, cortical cells and vasculature (Figure 7). No signal was observed in $3 \mathrm{~h}$ control ($\mathrm{Al}$ ) $\mathrm{T} 32$ and S70 root sections (Figure 7). In $12 \mathrm{~h} \mathrm{Al}$ treated T32 root tips, a strong signal was visible in the epidermis in addition to the vascular region; however, the signal appeared to be restricted to the epidermis and outer cortical cells in $12 \mathrm{~h}$ Al-treated S70 root tips. A positive signal was also observed in the epidermis, cortical cells and vasculature of $12 \mathrm{~h}$ control S70 roots (Figure 7) indicating the uniform expression of this gene under Al-free conditions. The intron-specific primers gave no positive signals (Figure 7). Overall, the localization of MATE expression in Al-treated root tips indicated that the transcript of the MATE gene accumulated most strongly in the vascular region of T32 and mainly in the epidermal and outer cortical layers in S70.

The MtMATE shares $67 \%$ identity with a putative lupin LaMATE (GenBank accession no. AAW30732; [64]), 63\% identity with a rice MATE gene (GenBank accession no. ABB47036), and 62\% identity with the Arabidopsis FRD3 protein (GenBank accession no. NP 187461.1; [65]). Based on studies conducted on different MATE genes it has been hypothesized that this family may be involved in transporting a diverse set of small organic molecules either directly out of the cell or into vacuolar compartments [65-67]. Recently, FRD3 was shown to be a citrate efflux transporter and Arabidopsis plants ectopically expressing FRD3 had significantly higher amounts of citrate in their root exudates compared to untransformed controls and possessed an enhanced resistance to aluminium [68]. Morin staining revealed presence of $\mathrm{Al}$ in the vasculature of T32 root tips at $12 \mathrm{~h}$ of Al treatment (Figure 5 ). Taking the differential root growth rates and $\mathrm{Al}$ accumulation patterns together with the spatial expression pattern of the MtMATE, it is tempting to speculate that the strong vascular expression of MtMATE in T32 root tips might be involved in transporting $\mathrm{Al}$ away from the sensitive growing root tip therefore resulting in lower root growth inhibition in T32. Internal detoxification of Al by formation of organic acid-Al complexes has been previously demonstrated in hydrangea and buckwheat $[15,69]$. In buckwheat, $\mathrm{Al}$ is chelated internally in the root cells by oxalate and translocated via the xylem to leaf cells where these complexes are then stored in vacuoles [70]. Likewise, it is possible that in T32 the MtMATE gene may be involved in the transport of organic acid-Al complexes into the aerial parts of the plant followed by sequestration into vacuoles. In S70, the organic acid efflux or Al-sequestration into vacuoles might be restricted to the root surface as indicated by the strong expression in the epidermal and cortical cells. In addition, it is possible that the observed expression of this gene under $\mathrm{Al}$-free conditions in $\mathrm{S} 70$ root tips is in response to low $\mathrm{pH}$ or low $\mathrm{pH}$ induced nutrient deficiencies. Interestingly, the LaMATE

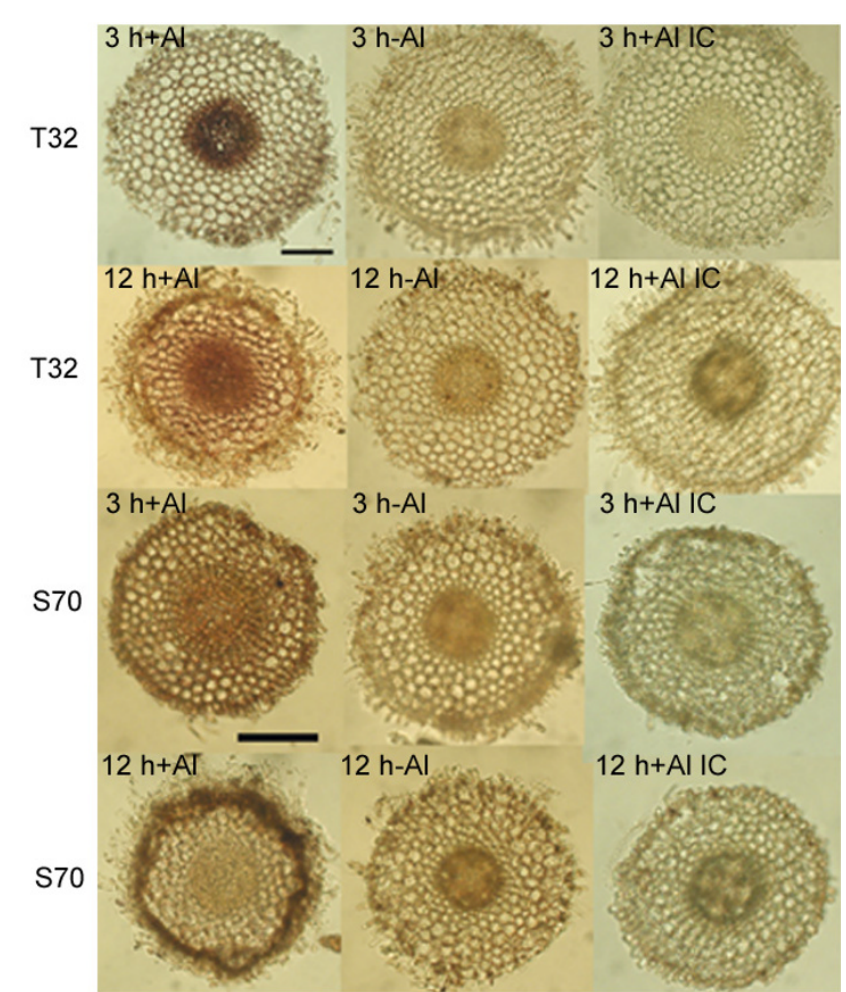

\section{Figure 7}

MtMATE gene expression in Al-treated and control T32 and S70 root tips. IC denotes in situ PCR using intron-specific primers. The images shown are representative of at least three independent experiments.

displays enhanced expression under various nutrient stress conditions including $-\mathrm{P},-\mathrm{Fe},-\mathrm{Mn},-\mathrm{N}$ and $+\mathrm{Al}$ [64]. Similarly, the FRD3 gene is induced in response to cold stress and during senescence (a search of 2,620 ATH1 Affymetrix chips in https://www.genevestigator.ethz.ch/ gv/index.jsp). Alternatively, although Al-induced expression of the MATE gene occurs in both lines, the subsequent activation of organic acid efflux might be delayed or inhibited in S70. Localization of MtMATE to either the plasma membrane or the vacuole would reveal its site of action, and identification of the molecule it transports could permit a direct biochemical test of its function in transport.

\section{Conclusion}

One of the most widely studied mechanisms of $\mathrm{Al}$ resistance is the $\mathrm{Al}$ exclusion and/or internal detoxification via organic acids (OA), which serve as $\mathrm{Al}$ chelators. However, induction of OA biosynthetic genes was not observed in this study. This finding was not surprising since, to date, no strong evidence exists for Al-induced expression of any of the enzymes catalyzing OA synthesis and metabolism [6]. Indeed, it is possible that OA biosynthetic enzymes are regulated translationally or post-translationally. In the 
present study we compared physiological and molecular differences between an Al- resistant and sensitive line, which enabled us to identify novel facets of $\mathrm{Al}$ resistance in Medicago truncatula. A number of Al-inducible genes with potential roles in $\mathrm{Al}$ resistance were identified in this study. For example, the Al-inducible MATE gene might be involved in organic acid exudation and internal detoxification of $\mathrm{Al}$ in $\mathrm{T} 32$, supporting the idea of an $\mathrm{Al}$ resistance mechanism involving organic acids in M. truncatula. Additionally, cell death of Al-accumulating cells in T32 represents a unique aspect of $\mathrm{Al}$ resistance in legumes. Our results provide a valuable data set for future studies targeted at investigating additional $\mathrm{Al}$ resistance responses.

\section{Methods \\ Plant material}

Seeds of 46 accessions of Medicago truncatula Gaertn. were obtained from the USDA-Western Regional Plant Introduction Station at Pullman, Washington, and seeds for another eight accessions (inbred lines) were obtained from INP-ENSAT, Toulouse, France. The selected accessions represent collections from different geographical locations and areas where acid soils are known to occur. To develop inbred lines from the USDA collection, one seed from each accession was grown in a greenhouse and self-pollinated. Seeds from these lines were used for subsequent experiments.

\section{Solution culture experiments}

Six M. truncatula seeds from each line were scarified using concentrated sulfuric acid and surface sterilized with 5\% (v/v) household beach for $3 \mathrm{~min}$. The seeds were placed at $4{ }^{\circ} \mathrm{C}$ for $2 \mathrm{~d}$ and germinated overnight on $1 \%$ agar plates in the dark at room temperature. Seedlings with radicles of about $1 \mathrm{~cm}$ in length were sown through the mesh bottoms of polypropylene cups. The cups were placed in precut holes of a plastic insert placed over a plastic tub that held $7.3 \mathrm{~L}$ of aerated nutrient solution. The nutrient solution contained: $1.2 \mathrm{mM} \mathrm{KNO}_{3}, 0.8 \mathrm{mM} \mathrm{Ca}\left(\mathrm{NO}_{3}\right)_{2}$, $0.1 \mathrm{mM} \mathrm{NH}_{4} \mathrm{H}_{2} \mathrm{PO}_{4}, 0.2 \mathrm{mM} \mathrm{MgSO}_{4}, 10 \mu \mathrm{M}$ FeNaEDTA, $50 \mu \mathrm{M} \mathrm{KCl}, 12.5 \mu \mathrm{M} \mathrm{H}_{3} \mathrm{BO}_{3}, 1 \mu \mathrm{M} \mathrm{MnSO}_{4}, 1 \mu \mathrm{M} \mathrm{ZnSO}_{4}$, $0.5 \mu \mathrm{M} \mathrm{CuSO}_{4}, 0.1 \mu \mathrm{M} \mathrm{Na}_{2} \mathrm{MoO}_{4}$, and $0.1 \mu \mathrm{M} \mathrm{NiCl}_{2}[71]$. The $\mathrm{pH}$ of the nutrient solution was adjusted to 4.5 using $1 \mathrm{~N} \mathrm{HCl}$. Seedlings were grown for $72 \mathrm{~h}$ in a growth chamber (light/dark, 14/10 h) under a light intensity of 440 $\mu \mathrm{mol}$ photons $\mathrm{m}^{-2} \mathrm{~s}^{-1}$. Al treatment was initiated after 72 $\mathrm{h}$ by replacing the control growth solution with an identical solution that contained $2.5 \mu \mathrm{M} \mathrm{Al}$ added as $\mathrm{AlK}\left(\mathrm{SO}_{4}\right)_{3}$. The control and treatment solutions were adjusted to $\mathrm{pH}$ 4.5. Root growth measurements were made at 0 and $48 \mathrm{~h}$ following Al exposure. Relative root growth was calculated as: RRG $(\%)=$ (root growth in Al solution/root growth in control solution) $\times 100$. The RRG value of each line was normalized to that of M. truncatula Jemalong A17 to account for any variation in solution $\mathrm{pH}$ or composition in the different tubs.
For the dose-response experiments, plants were grown in 0 (control), 1.25, 2.5, 5.0 and $10 \mu \mathrm{M} \mathrm{Al}$ solutions, and root growth measurements were made at $48 \mathrm{~h}$ following Al exposure. For the time-course experiments, root growth measurements were made at $0,12,24,48$ and $72 \mathrm{~h}$ in 0 $\mu \mathrm{M}$ (control) and $2.5 \mu \mathrm{M} \mathrm{Al}$ solutions. These experiments were performed in triplicate.

\section{Hematoxylin and morin staining}

For hematoxylin staining, control and Al treated roots were rinsed for $30 \mathrm{~min}$ in deionized water, with the water replaced twice during rinsing. Roots were then stained with hematoxylin $(0.1 \% \mathrm{w} / \mathrm{v}$ hematoxylin, $0.01 \% \mathrm{w} / \mathrm{v}$ $\mathrm{KIO}_{3}$ ) for $30 \mathrm{~min}$, and subsequently washed with deionized water for $30 \mathrm{~min}$. For morin staining, control and $\mathrm{Al}$ treated roots were washed in MES buffer, $\mathrm{pH}$ 5.5, for 10 min, and stained with $100 \mu \mathrm{M}$ morin in the same buffer for $1 \mathrm{~h}$, as described previously [72]. Morin fluorescence was visualized using an Olympus inverted microscope (IX70, Olympus, NY) with fluorescence attachments.

\section{Evans blue quantification}

Evans blue is a stain that indicates the loss of plasma membrane integrity of cells. Control and Al treated roots were rinsed with deionized water and stained with Evans blue solution $\left(0.025 \%\right.$ [w/v] Evans blue in $100 \mu \mathrm{M} \mathrm{CaCl}_{2}$, $\mathrm{pH} \mathrm{5.6)}$ for $10 \mathrm{~min}$. The stained roots were washed three times with $100 \mu \mathrm{M} \mathrm{CaCl}_{2}$ (pH 5.6), until dye no longer eluted from the roots. Evans blue stain retained by cells was quantified as described [73] with minor modifications

\section{Plant growth conditions, Al treatment and tissue collection for microarrays}

For the microarray experiment, T32 and S70 seedlings were grown in solution culture as described above. Root tips (approximately $0.5 \mathrm{~cm}$ in length) from control and $2.5 \mu \mathrm{M} \mathrm{Al}$ treated seedlings were harvested at 12 and $48 \mathrm{~h}$ after Al treatment and immediately frozen in liquid nitrogen. Samples were collected from three independent biological replicates and stored at $-80^{\circ} \mathrm{C}$. To verify phenotype of roots harvested for RNA isolation, root growth measurements of 12 sample roots were made at 0,12 and $48 \mathrm{~h}$ following $\mathrm{Al}$ exposure.

\section{Microarray hybridization and analysis}

Total RNA from control and Al-treated root tips was extracted using the RNeasy Plant Mini Kit (Qiagen, Alameda, CA) following the manufacturer's protocol. RNA was quantified spectrophotometrically and stored at $-80^{\circ} \mathrm{C}$ before use. cDNA synthesis was carried out using a 3DNA Array 900 Expression Array Detection Kit (Genisphere, Inc., Hatsfield, PA) according to the manufacturer's instructions (3DNA Array 900 Expression Array Detection Kit, Appendix A, Genisphere). 
Table 4: Primer sequences used for quantitative RT-PCR.

\begin{tabular}{|c|c|c|}
\hline TIGR TC & Forward Primer & Reverse Primer \\
\hline TCI05342 & 5'-САТСССТСТСТTGСАССАТСА-3' & 5'-TTTCCACTTCTTGTTGGGTTCA-3' \\
\hline TCI022II & 5'-TCCAGCTCCACAACCTAGCA-3' & 5'-TGCATCGTGGTCCACATTCT-3' \\
\hline TC95697 & 5'-GGTGTCGAAGGTGGCCATAG-3' & 5'-TCAGCACGACCGTAAAATCTTG-3' \\
\hline TCI00486 & 5'-CATCTGGAAGCCACAACACATTA-3' & 5'-GTTGGTTCTTTGGGAATGGAATAC-3' \\
\hline TCIII92 & 5'-AGTGCAACTGTTGCTTGCACAA-3' & 5'-CCATAAGCATTCCAACAAAAAGG-3' \\
\hline TC96658 & 5'-GCTGAGGTGGGTGCAGAAGA-3' & 5'-GAGACTAAGAGTGAGTGCATTCAACTG-3' \\
\hline TC93997 & 5'-GTGGTCAAGCTTCTTGTGGAAAG-3' & 5'-CAACCCTCCATTGCTGCATT-3' \\
\hline TCI0377I & 5'-TGGCAGGGAGAGGACAGTTG-3' & 5'-CGGCTGGTGTTCTACCAGAAG-3' \\
\hline TC95I54 & 5'-GTAGCTCTGTCAGGAGGGCATAC-3' & 5'-AACGAAGGGTCCACGTCATG-3' \\
\hline $\mathrm{TC} 100155$ & 5'-TTGAGATTTCTTCTGCAGTTTACAAGA-3' & 5'-GGAAGAGGGATCCTCAACAGCCTA-3' \\
\hline TCI0I956 & 5'-ACCTCATAGTGGGTTGCCAAA-3' & 5'-ATAACCTCСTCCCATGTTGTACACA-3' \\
\hline TCI03586 & 5'-TGAATGCAAAACGTGCAACA-3' & 5'-TGAGTTCTTCACCTTCAGCTAGTTTC-3' \\
\hline I8s rDNA & 5'-CCTCAAACTTCCGTGGCCTAA-3' & 5'-TAACGAACGAGACCTCAGCCTG-3' \\
\hline
\end{tabular}

The Medicago truncatula AROS (version 1.0) arrays (Operon Biotechnologies Inc., Huntsville, AL) containing 16,08670 mer probes representing 16,086 M. truncatula genes were used for the microarray studies. The 70 mer probes were printed on Telechem Super Amine slides (Sunnyvale, CA) with spot size approximately 100 to 110 $\mu \mathrm{m}$ in diameter. Slides were processed prior to use by rehydrating over a $50^{\circ}$ to $55^{\circ} \mathrm{C}$ water bath for 5 to $10 \mathrm{sec}$ and snap-drying on a $65^{\circ} \mathrm{C}$ heating block for $5 \mathrm{sec}$, approximately three to four times. The DNA on the slide was cross linked by exposing the DNA-side-up to $65 \mathrm{~mJ}$ in a UV crosslinker. The slides were washed in 1\% SDS at room temperature for $5 \mathrm{~min}$, dipped in 100\% ethanol for $30 \mathrm{sec}$ with gentle agitation, centrifuged at 1,500 rpm for 2 to $5 \mathrm{~min}$ and stored in a light-proof box under cool and dry conditions before use. Microarrays for each time point were hybridized to cDNAs from both Al-treated and control roots, with cDNAs from the two different treatments labeled with Cy5 and Cy3 dyes. Each hybridization was repeated at least six times to account for technical variability, with triplicates of each dye combination to control for dye effects. A modified two-step hybridization reaction was performed as described in the 3DNA Array 900 Expression Array Detection Kit (Genisphere). Slide scanning and data analysis was performed as described in [74].

\section{Quantitative reverse transcription PCR}

Root tip RNA samples from the three biological replicates that were used for microarray experiments were used for quantitative real-time PCR (q-PCR) assays. Primers for qPCR reactions were designed using the Primer Express software (v 2.0, Applied Biosystems, Foster City, CA) and are presented in Table 4. RNA extraction and PCR conditions are as described previously [75]. For each biological replicate, three q-PCR reactions were run from a cDNA synthesis and the mean values presented. Amplification of $18 \mathrm{~S}$ ribosomal RNA was used as the endogenous control. The $\Delta \Delta \mathrm{Ct}$ (threshold cycle) method was used to calculate relative fold changes between Al-treated and control (-Al) cDNA samples. Specificity of the product was confirmed by a single peak in a dissociation curve at the end of the PCR reaction.

\section{In-well in situ PCR on root tip sections}

T32 and S70 seedlings were grown in solution culture as described for the microarray tissue collection and root tips (approximately $0.5 \mathrm{~cm}$ in length) were harvested from control $(0 \mu \mathrm{M})$ and $\mathrm{Al}(2.5 \mu \mathrm{M})$ treated seedlings at 3 and $12 \mathrm{~h}$ following Al exposure. In situ PCR on root tissue was carried out as described [76] with minor modifications. The root tips were fixed in $4 \%$ paraformaldehyde, $0.25 \%$ glutaraldehyde, $0.003 \mathrm{~N}$ sodium hydroxide, and $1 \%$ Tween 20 in $100 \mathrm{mM}$ PIPES buffer (pH 6.8). The MATE exon primer for the reverse transcription reaction was 5 'AGCAATGGAAACTCCAGCAGC-3' and the primers for the PCR reaction were MATE exon forward, 5'-CATCCCTCTCTTGCACCATCA-3'or MATE intron forward, 5'GCAAAGAGGAACAATGGCGA-3' and MATE exon reverse, 5'-AGCAATGGAAACTCCAGCAGC-3'. The sections were examined under a microscope and photographed with a digital camera (Nikon Coolpix 900).

\section{Authors' contributions}

DC and DAS conceived the study and wrote most of the paper. DC and DFG conceived the physiological characterization of the $\mathrm{Al}$ resistant and sensitive lines, while DC and DAS conceived the molecular characterization of the two lines. NS performed the statistical analyses of the microarray data and uploaded the data onto Gene Omnibus. KAV improved the overall quality of the manuscript. All authors read and approved the final manuscript.

\section{Acknowledgements}

We thank Dr. David Galbraith (University of Arizona) for printing of microarrays and Dr. Dasharath P. Lohar (University of Minnesota) for assistance with microarray slide scanning. We also thank Dr. Mark Sanders at the University of Minnesota - College of Biological Sciences, Imaging Center, http:/ 
/www.cbs.umn.edu/ic/ for assistance with fluorescence microscopy. We acknowledge support from the University of Minnesota Super Computing Institute for data analysis.

This work was partially supported by the National Science Foundation Plant Genome Project (award no. 0I 10206). Mention of trade names or commercial products in the article is solely for the purpose of providing specific information and does not imply recommendations or endorsement by the U.S. Department of Agriculture.

\section{References}

I. Foy CD, Chaney RL, White MC: The physiology of metal toxicity in plants. Ann Rev Plant Physiol 1978, 29:5 I I-566.

2. Von-Uexküll HR, Mutert E: Global extent, development and economic impact of acid soils. Plant Soil 1995, I 71 : |- | 5 .

3. Kinraide TB: Identity of the rhizotoxic aluminium species. In Plant-Soil Interactions at Low pH Edited by: Wright RJ, Baligar VC, Murrmann RP. Dordrecht: Kluwer Academic Publishers; 1991:717-728.

4. Cook DR: Medicago truncatula: a model in the making! Cur Opinion Plant Biol 1999, 2:301-304

5. Ryan PR, Ditomaso JM, Kochian LV: Aluminum toxicity in roots: An investigation of spatial sensitivity and the role of the root cap. J Exp Bot 1993, 44:437-446.

6. Kochian LV, Piñeros MA, Hoekenga OA: The physiology, genetics and molecular biology of plant aluminum resistance and toxicity. Plant Soil 2005, 274: I75-195.

7. Ma JF, Shen R, Nagao S, Tanimoto E: Aluminum targets elongating cells by reducing cell wall extensibility in wheat roots. Plant Cell Physiol 2004, 45:583-589.

8. Sivaguru M, Fujiwara T, Samaj J, Baluska F, Yang Z, Osawa H, Maeda T, Mori T, Volkmann D, Matsumoto H: Aluminum-induced I,3- $\beta$ D-glucan inhibits cell-to-cell trafficking of molecules through plasmodesmata. A new mechanism of aluminum toxicity in plants. Plant Physiol 2000, I 24:991-1005

9. Ahn SI, Sivaguru M, Chung GC, Rengel Z, Matsumoto H: Aluminium-induced growth inhibition is associated with impaired efflux and influx of $\mathrm{H}^{+}$across the plasma membrane in root apices of squash (Cucurbita pepo). J Exp Bot 2002, 53: 1959-1966.

10. Rengel Z, Zhang WH: Role of dynamics of intracellular calcium in aluminum-toxicity syndrome. New Phytol 2003, I 59:295-3 I4.

I. Blancaflor EB, Jones DL, Gilroy S: Alterations in the cytoskeleton accompany aluminum-induced growth inhibition and morphological changes in the primary roots of maize. Plant Physiol 1998, I I 8:159-172.

12. Matsumoto $\mathrm{H}$ : Changes of the structure of pea chromatin by aluminum. Plant Cell Physiol 1988, 29:281-287.

13. Bounejmate $M$, Robson AD: Differential tolerance of genotypes of Medicago truncatula to low pH. Aus J Agric Res 1992 , 43:73I-737.

14. Sledge MK, Pechter P, Payton ME: Aluminum tolerance in Medicago truncatula germplasm. Crop Sci 2005, 45:200 I-2005.

15. Ma JF, Hiradate $\mathrm{S}$, Matsumoto $\mathrm{H}$ : High aluminum resistance in buckwheat. II. Oxalic acid detoxifies aluminum internally. Plant Physiol 1998, I I 7:753-759.

16. Pellet DM, Papernik LA, Jones DL, Darrah PR, Grunes DL, Kochian LV: Involvement of multiple aluminum exclusion mechanisms in aluminum tolerance in wheat. Plant Soil 1997, 192:63-68.

17. Wenzl P, Patino GM, Chaves AL, Mayer JE, Rao IM: The high level of aluminum resistance in signalgrass is not associated with known mechanisms of external aluminum detoxification in root apices. Plant Physiol 200 I, I 25: |473-I484.

18. Nian H, Yang Z, Huang H, Yan X, Matsumoto H: Citrate secretion induced by aluminum stress may not be a key mechanism responsible for differential aluminum tolerance of some soybean genotypes. J Plant Nut 2004, 27:2047-2066.

19. Piñeros MA, Shaff JE, Manslank HS, Alves VM, Kochian LV: Aluminum resistance in maize cannot be solely explained by root organic acid exudation. A comparative physiological study. Plant Physiol 2005, 137:231-24I.

20. Delhaize E, Ryan PR, Randall PJ: Aluminum tolerance in wheat (Triticum aestivum L.). II. Aluminum-stimulated excretion of malic acid from root apices. Plant Physiol 1993, 1 03:695-702.
21. Zheng SJ, Ma JF, Matsumoto $\mathrm{H}$ : Continuous secretion of organic acids is related to aluminum resistance during relatively long-term exposure to aluminum stress. Physiol Plant 1998, I03:209-2|4.

22. Li XF, Ma JF, Matsumoto $\mathrm{H}$ : Pattern of aluminum-induced secretion of organic acids differs between rye and wheat. Plant Physiol 2000, I 23: I 537-I543.

23. Piñeros MA, Magalhaes JV, Carvalho Alves VM, Kochian LV: The physiology and biophysics of an aluminum tolerance mechanism based on root citrate exudation in maize. Plant Physio 2002, I 29: I 194-1206.

24. Yang $\mathrm{Z}$, Yang $\mathrm{H}$, Wang J, Wang $\mathrm{Y}$ : Aluminum regulation of citrate metabolism for $A l$-induced citrate efflux in the roots of Cassia tora L. Plant Sci 2004, I 66: I589-1594.

25. Cruz-Ortega R, Ownby JD: A protein similar to PR (pathogenesis-related) proteins is elicited by metal toxicity in wheat roots. Physiol Plant 1993, 89:21 I-219.

26. Ezaki $B$, Yamamoto $Y$, Matsumoto $\mathrm{H}$ : Cloning and sequencing of the cDNAs induced by aluminum treatment and Pi starvation in cultured tobacco cells. Physiol Plant 1995, 93: I I- I8.

27. Snowden KC, Richards KD, Gardner RC: Aluminum-induced genes. Induction by toxic metals, low calcium, and wounding and pattern of expression in root tips. Plant Physiol 1995, I 07:34|-348.

28. Hamel F, Breton C, Houde M: Isolation and characterization of wheat aluminum-regulated genes: possible involvement of aluminum as a pathogenesis response elicitor. Planta 1998, 205:531-538.

29. Richards KD, Schott EJ, Sharma YK, Davis KR, Gardner RC: Aluminum induces oxidative stress genes in Arabidopsis thaliana. Plant Physiol 1998, I | 6:409-4 I8.

30. Rodriguez Milla MA, Butler E, Huete AR, Wilson CF, Anderson O, Gustafson JP: Expressed sequence tag-based gene expression analysis under aluminum stress in rye. Plant Physiol 2002, 130:1706-1716

31. Chandran D, Sharopova N, Ivashuta S, Gantt JS, VandenBosch KA, Samac DA: Transcriptome profiling identified novel genes associated with aluminum toxicity, resistance and tolerance in Medicago truncatula. Planta 2008, 228: I5 I-166.

32. Singhal A, Keefer KD: A study of aluminium speciation in aluminium chloride solutions by small angle $x$-ray scattering and ${ }^{27}$ AI NMR. J Mater Res 1994, 9:1973-1983.

33. Kinraide TB: Aluminum enhancement of plant growth in acid rooting media. A case of reciprocal alleviation of toxicity by two toxic cations. Physiol Plant 1993, 88:619-625.

34. Clune TS, Copeland L: Effects of aluminum on canola roots. Plant Soil 1999, 2 I 6:27-33.

35. Tomioka R, Oda A, Takenaka C: Root growth enhancement by rhizospheric aluminium treatment in Quercus serrata Thunb. seedlings. J Forest Res 2005, 1 0:319-324.

36. Gunse B, Poschenrieder C, Barcelü J: The role of ethylene metabolism in the short-term responses to aluminum by roots of two maize cultivars different in Al-resistance. Environ Exp Bot 2000, 43:73-8।.

37. Polle $E$, Konzak CF, Kittrick JA: Visual detection of aluminium tolerance levels in wheat by hematoxylin staining of seedling roots. Crop Sci 1978, I 8:823-827.

38. Cancado GMA, Loguercio LL, Martins PR, Parentoni SN, Paiva E, Borem A, Lopes MA: Hematoxylin staining as a phenotypic index for aluminum tolerance selection in tropical maize (Zea mays L.). Theor Appl Genet 1999, 99:747-754.

39. Tusher VG, Tibshirani R, Chu G: Significance analysis of microarrays applied to the ionizing radiation response. Proc Nat Acad Sci USA 2001, 98:5116-5121.

40. Arnholdt-Schmitt B: Stress-induced cell reprogramming. A role for global genome regulation? Plant Physiol 2004 136:2579-2586

41. Dowd C, Wilson IW, McFadden H: Gene expression profile changes in cotton root and hypocotyl tissues in response to infection with Fusarium oxysporum f. sp. vasinfectum. Mol PlantMicrobe Interact 2004, 1 7:654-667.

42. Manthey K, Krajinski F, Hohnjec N, Firnhaber C, Puhler A, Perlick $A M$, Kuster $\mathrm{H}$ : Transcriptome profiling in root nodules and arbuscular mycorrhiza identifies a collection of novel genes induced during Medicago truncatula root endosymbioses. Mol Plant-Microbe Interact 2004, 17:1063-1077. 
43. Schmohl N, Horst WJ: Cell wall pectin content modulates aluminum sensitivity of Zea mays (L.) cells grown in suspension culture. Plant Cell Environ 2000, 23:735-742.

44. Wen F, Zhu Y, Hawes MC: Effect of pectin methylesterase gene expression on pea root development. Plant Cell 1999, I I:I I29-I| 40.

45. Schmohl N, Pilling J, Fisahn J, Horst WJ: Pectin methylesterase modulates aluminum sensitivity in Zea mays and Solanum tuberosum. Physiol Plant 2000, I09:419-427.

46. Eticha D, Stass A, Horst WJ: Cell-wall pectin and its degree of methylation in the maize root-apex: significance for genotypic differences in aluminum resistance. Plant Cell Env 2005, 28: $1410-1420$

47. Delisle G, Champoux M, Houde M: Characterization of oxalate oxidase and cell death in Al-sensitive and tolerant wheat roots. Plant Cell Physiol 200I, 42:324-333.

48. Boscolo PR, Menossi M, Jorge RA: Aluminum-induced oxidative stress in maize. Phytochemistry 2003, 62:181-189.

49. Apel K, Hirt H: Reactive oxygen species: metabolism, oxidative stress, and signal transduction. Annu Rev Plant Biol 2004, 55:373-399.

50. Munne-Bosch S: The role of alpha-tocopherol in plant stress tolerance. I Plant Physiol 2005, 162:743-748.

5I. Dixon RA, Achnine L, Kota P, Liu C, Reddy MSS, Wang L: The phenylpropanoid pathway and plant defence- a genomics perspective. Mol Plant Pathol 2002, 3:37|-390.

52. Rice-Evans CA, Miller NJ, Bolwell PG, Bramley PM, Pridham JB: The relative activities of plant-derived polyphenolic flavonoids. Free Radical Res 1995, 22:375-383.

53. Halliwell B: Reactive species and antioxidants. Redox biology is a fundamental theme of aerobic life. Plant Physiol 2006, | $41: 312-322$.

54. Johnson KL, Jones BJ, Bacic A, Schultz CJ: The fasciclin-like arabinogalactan proteins of Arabidopsis. A multigene family of putative cell adhesion molecules. Plant Physiol 2003, |33:191|-1925.

55. Schindler T, Bergfeld R, Schopfer P: Arabinogalactan proteins in maize coleoptiles: developmental relationship to cell death during xylem differentiation but not to extension growth. Plant J 1995, 7:25-36.

56. Schultz CJ, Rumsewicz MP, Johnson KL, Jones BJ, Gaspar YM, Bacic A: Using genomic resources to guide research directions. The arabinogalactan protein gene family as a test case. Plant Physiol 2002, I 29: | 448-| 463.

57. Ezaki B, Tsugita S, Matsumoto H: Expression of a moderately anionic peroxidase is induced by aluminum treatment in tobacco cells: Possible involvement of peroxidase isozymes in aluminum ion stress. Physiol Plant 1996, 96:21-28.

58. Mano J, Torii Y, Hayashi S, Takimoto K, Matsui K, Nakamura K, Inze D, Babiychuk E, Kushnir S, Asada K: The NADPH: quinone oxidoreductase PI-zeta-crystallin in Arabidopsis catalyzes the alpha, beta-hydrogenation of 2-alkenals: detoxication of the lipid peroxide-derived reactive aldehydes. Plant Cell Physiol 2002, 43: | 445-|455.

59. Mao C, Yi K, Yang L, Zheng B, Wu Y, Liu F, Wu P: Identification of aluminum-regulated genes by cDNA-AFLP in rice (Oryza sativa L.): aluminum-regulated genes for the metabolism of cell wall components. J Exp Bot 2004, 55:137.

60. Ezaki B, Gardner RC, Ezaki Y, Matsumoto H: Expression of aluminum-induced genes in transgenic Arabidopsis plants can ameliorate aluminum stress and/or oxidative stress. Plant Physiol 2000, I 22:657-665.

61. Pan J, Zhu M, Chen H: Aluminum-induced cell death in root-tip cells of barley. Environ Exp Bot 200I, 46:71-79.

62. Simonovicova M, Huttova J, Mistrik I, Siroka B, Tamas L: Root growth inhibition by aluminum is probably caused by cell death due to peroxidase-mediated hydrogen peroxide production. Protoplasma 2004, 224:91-98.

63. Gechev TS, Van Breusegem F, Stone JM, Denev I, Laloi C: Reactive oxygen species as signals that modulate plant stress responses and programmed cell death. Bioessays 2006, 28: $1091-1101$.

64. Uhde-Stone C, Liu J, Zinn KE, Allan DL, Vance CP: Transgenic proteoid roots of white lupin: a vehicle for characterizing and silencing root genes involved in adaptation to $\mathbf{P}$ stress. Plant J 2005, 44:840-853.
65. Rogers EE, Guerinot ML: FRD3, a member of the multidrug and toxin efflux family, controls iron deficiency responses in Arabidopsis. Plant Cell 2002, I4: I787-I799.

66. Morita Y, Kataoka A, Shiota S, Mizushima T, Tsuchiya T: NorM of Vibrio parahaemolyticus is an $\mathbf{N a ( + )}$-driven multidrug efflux pump. J Bacteriol 2000, I 82:6694-6697.

67. Li L, He Z, Pandey GK, Tsuchiya T, Luan S: Functional cloning and characterization of a plant efflux carrier for multidrug and heavy metal detoxification. J Biol Chem 2002, 277:5360-5368.

68. Durrett TP, Gassmann W, Rogers EE: The FRD3-mediated efflux of citrate into the root vasculature is necessary for efficient iron translocation. Plant Physiol 2007, I44:197-205.

69. Ma JF, Hiradate S, Nomoto K, Iwashita T, Matsumoto H: Internal detoxification mechanism of $\mathbf{A l}$ in hydrangea. Plant Physio 1997, I I 3:1033-1039.

70. Ma JF, Hiradate S: Form of aluminum for uptake and translocation in buckwheat (Fagopyrum esculentum Moench). Planto 2000, 2 I I :355-360.

7I. Pence NS, Larsen PB, Ebbs SD, Letham DL, Lasat MM, Garvin DF, Eide $D$, Kochian LV: The molecular physiology of heavy metal transport in the $\mathrm{Zn} / \mathbf{C d}$ hyperaccumulator Thlaspi caerulescens. Proc Natl Acad Sci USA 2000, 97:4956-4960.

72. Larsen PB, Tai $\mathrm{CH}$, Kochian LV, Howell $\mathrm{SH}$ : Arabidopsis mutants with increased sensitivity to aluminum. Plant Physiol 1996, I | 0:743-75 I

73. Yamamoto $\mathrm{Y}, \mathrm{Kobayashi} \mathrm{Y}$, Matsumoto $\mathrm{H}$ : Lipid peroxidation is an early symptom triggered by aluminum, but not the primary cause of elongation inhibition in pea roots. Plant Physiol $200 \mathrm{I}$ 125:199-208.

74. Lohar DP, Sharopova N, Endre G, Penuela S, Samac D, Town C, Silverstein $\mathrm{KA}$, VandenBosch KA: Transcript analysis of early nodulation events in Medicago truncatula. Plant Physiol 2006, | 40:22 I-234.

75. Tesfaye $M$, Samac DA, Vance CP: Insights into symbiotic nitrogen fixation in Medicago truncatula. Mol Plant-Microbe Interact 2006, 3:330-34I.

76. Koltai H, Bird DM: High throughput cellular localization of specific plant $m R$ NAs by liquid-phase in situ reverse transcription-polymerase chain reaction of tissue sections. Plant Physiol 2000, I 23:1203-1212.
Publish with Biomed Central and every scientist can read your work free of charge

"BioMed Central will be the most significant development for disseminating the results of biomedical research in our lifetime. "

Sir Paul Nurse, Cancer Research UK

Your research papers will be:

- available free of charge to the entire biomedical community

- peer reviewed and published immediately upon acceptance

- cited in PubMed and archived on PubMed Central

- yours - you keep the copyright
BioMedcentral 